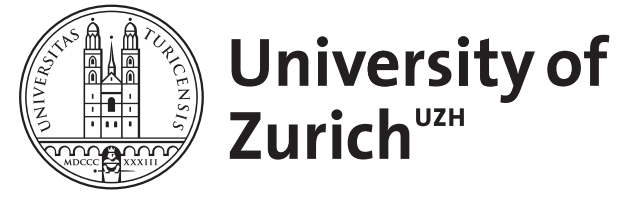

\title{
Bonus schemes and trading activity
}

\author{
Pikulina, Elena ; Renneboog, Luc ; Ter Horst, Jenke ; Tobler, Philippe N
}

\begin{abstract}
Little is known about how different bonus schemes affect traders' propensity to trade and which bonus schemes improve traders' performance. We study the effects of linear versus threshold bonus schemes on traders' behavior. Traders buy and sell shares in an experimental stock market on the basis of fundamental and technical information (past share price evolution, realized earnings, analysts' earnings forecasts, and evolution of the market index). We find that linear and threshold bonus schemes have different effects on trading behavior: traders make more transactions but of a smaller size under the threshold than under the linear bonus scheme. Furthermore, transaction frequency significantly decreases when bonus thresholds are reached but only after building in a safety margin. Under the threshold scheme, the traders' performance is lower (even when there are no transaction costs) than under the linear bonus scheme as a consequence of poorer market timing. This is especially the case when earning money by trading is relatively difficult (i.e., under low profitability conditions). Nevertheless, under low profitability conditions, traders seem to collect more information about the relationships between share price and market returns, earnings, and earnings forecasts, put more effort into understanding those relationships, and thus eventually learn to perform better.
\end{abstract}

DOI: https://doi.org/10.1016/j.jcorpfin.2014.09.010

Posted at the Zurich Open Repository and Archive, University of Zurich

ZORA URL: https://doi.org/10.5167/uzh-113900

Journal Article

Accepted Version

Originally published at:

Pikulina, Elena; Renneboog, Luc; Ter Horst, Jenke; Tobler, Philippe N (2014). Bonus schemes and trading activity. Journal of Corporate Finance, 29:369-389.

DOI: https://doi.org/10.1016/j.jcorpfin.2014.09.010 


\title{
BONUS SCHEMES AND TRADING ACTIVITY
}

\author{
ELENA PIKULINA \\ LUC RENNEBOOG \\ JENKE TER HORST \\ PHILIPPE TOBLER ${ }^{1}$
}

\begin{abstract}
Little is known about how different bonus schemes affect traders' propensity to trade and which bonus schemes improve traders' performance. We study the effects of linear versus threshold (convex) bonus schemes on traders' behavior. Traders purchase and sell shares in an experimental stock market on the basis of fundamental and technical information (evolution of the market index, past share price evolution, realized earnings, and analysts' earnings forecasts). We find that traders trade more intensively (the number of transactions augments) under the threshold than under the linear bonus scheme. When market conditions are such that a higher profitability can be more easily reached, trading frequency only increases little under a threshold scheme, but the size of trades is significantly larger than in the case of market conditions with lower profitability. Furthermore, trading intensity significantly decreases when bonus thresholds are reached but only after building in a safety margin. Under the threshold scheme, the traders' performance is lower (even when there are no transaction costs) than under the linear bonus scheme as a consequence of poorer market timing. This is especially the case when earning money by trading is relatively difficult (under low profitability conditions). Nevertheless, under low profitability conditions, traders seem to collect more information about the relationships between share price and market returns, earnings, and earnings forecasts, apply more effort to understand those relationships, and finally show better performance.
\end{abstract}

\section{JEL Classification: G11, J33}

\section{Keywords: Bonus, Compensation, Investment Decisions, Trading Behavior}

Acknowledgments: We are grateful to Ralf Bergheim, Giles Binchois, Peter Bossaerts, Fabio Braggion, Evy Bruyland, Eddy Cardinaels, Peter Cziraki, Valerie De Bruyckere, Frank de Jong, Marc Deloof, Joost Driessen, Martin Fochmann, Rik Frehen, Peter de Goeij, Johan Groothaert, Joyce Wu Keyu, Thomas Lambert, Marc Levy, Alberto Manconi, Charles Noussair, Rik Pieters, Jan Potters, Steven Raets, Wim Scherpereel, and Oliver Spalt for useful comments and suggestions. We also acknowledge the contribution of our discussants Jonas Standaert at the Belgian Finance Research Forum at the University of Antwerp (2012), Daniel Kleinlercher at the Experimental Finance Conference, University of Luxembourg (2012), and the participants in the International ESA Conference in New York (2012). All remaining errors are our own. We gratefully acknowledge financial support from the AXA foundation (Elena Pikulina) and Inquire Europe (Renneboog and Ter Horst).

\footnotetext{
${ }^{1}$ Elena Pikulina, Luc Renneboog, and Jenke ter Horst are from Tilburg University; Philippe Tobler is from the University of Zurich. E-mails: e.pikulina@uvt.nl, luc.renneboog@uvt.nl, j.r.terhorst@uvt.nl, and phil.tobler@econ.uzh.ch. We would like to thank Inquire Europe and AXA Research Fund for providing funds for this project.
} 


\section{Introduction}

The role of compensation schemes as a device to reduce agency costs has raised academic eyebrows over the last fifteen years (Bebchuk \& Fried, 2004). The recent financial crisis has intensified this criticism not only in the academic literature but also on the part of investors and regulators. Public opinion is reflected in the observation of Timothy Geithner, the former US Treasury Secretary: "This financial crisis had many significant causes, but executive compensation practices were a contributing factor. Incentives for short term gains overwhelmed the checks and balances meant to mitigate against the risk of excess leverage" (Geithner, 2009). Whereas the relationship between the level and form of executive compensation and company performance has frequently been studied, little is known about how compensation packages and bonus schemes actually create incentives for traders.

Bonus schemes seem to play an eminent role in traders' motivation to trade and to perform well. Sometimes they evoke emotions, aspirations, and risk appetites that result in aberrant behavior, e.g., in the cases of Nick Leeson, Jérôme Kerviel, and Kweku Adoboli, whose fraudulent behavior cost their employers around Euro 8 billion. "Yes, I did it - but all I wanted was a bonus," commented Jérôme Kerviel on his trading loss of Euro 4.9 billion for Societe Generale (The Independent and The Times, 29 Oct. 2008). In a similar vein, Nick Leeson commented "I suppose, I became indoctrinated by the lure of the salaries that were available and the whispered rumours of bonuses that were available" (Journal.ie, 19 Oct. 2011). These examples show that a misalignment of the interests of individuals and their employers (be it mutual funds, unit trusts, banks, pension funds, or corporations) may lead to severe problems. It is likely that specific compensation schemes induce suboptimal trading behavior that may ultimately lead to poor performance and significant corporate losses. However, still little is known about how bonus schemes affect traders' propensity to trade and which bonus schemes improve traders' performance.

To our knowledge, this is the first study to investigate the influence of bonus schemes on traders' willingness to trade and on their performance. In contrast, a considerable number of studies have been made on fund managers' (but not on traders' incentives). A broad literature postulates a convex relationship between fund managers' compensation and funds' past performance through new money inflows and investigates fund managers' response to those incentives (Kempf, Ruenzi, \& Thiele 2009; Farnsworth \& Taylor 2006; Chevalier and Ellison 1997). Although from a theoretical perspective convex compensation schemes should 
lead to higher risk taking and higher profits compared to linear ones, Coval and Shumway (2005) and Liu et al. (2010) find that higher risk-taking does not result in higher returns for professional traders and market makers.

Traders' bonus schemes may serve roles other than inducing traders to higher risktaking. For example, they may be designed to increase trading intensity. This would be particularly relevant if a professional market maker would earn higher profits by placing more trades or larger trades. However, empirical evidence suggests that such strategies also do not necessarily lead to increased performance. Indeed, Garvey and Wu (2010) document that for professional traders higher trading activity on the last day of their evaluation period results in poorer performance due to higher transaction costs and poor market timing. Likewise, Barber and Odean $(2000,2001)$ demonstrate that for individual investors higher trading activity is likely to result in poorer performance due to higher transaction costs.

To investigate how traders react to different incentive schemes, we set up an experiment to study trading behavior under controlled market conditions. Specifically, we study trading intensity and performance. We compare the impact of two different bonus schemes: (i) a linear scheme, which we use as benchmark and always pays a fixed percentage of the total profit; and (ii) a threshold scheme, which is frequently used in the industry and pays an increased percentage of the total profit as each threshold is reached (after which the payment increases linearly until the next threshold is reached). Linear, but especially threshold bonus schemes are widely used by banks and funds, but the amounts, thresholds, and other details seem strictly confidential. ${ }^{2}$

In a wider context, our study relates to the literature on the effects of incentives on performance in psychology and economics. In their overview based on 131 experimental papers, Bonner et al. (2000) show that quota schemes are the most likely to evoke positive incentive effects, such as higher effort levels or higher performance. A quota scheme is an example of a threshold scheme; it pays a lump-sum amount once a certain performance level is reached, i.e., it involves a specific goal. In terms of providing incentives to improve performance, threshold schemes are followed by linear ones, tournaments, and fixed-rate

\footnotetext{
${ }^{2}$ We have verified that our bonus schemes are realistic. Directors and traders of UBS, Goldman Sachs, JP Morgan, Meryll Lynch, and Deutsche Bank London stated that the thresholds and degree of profit sharing not only depend on the individual performance of the traders but also on their seniority, hierarchical rank, and the profitability of the department, division, and firm. They have confirmed that our schemes do make sense and are used in practice, although they were not willing to provide details or give examples of the threshold values or profit-sharing rules used in their companies.
} 
schemes $^{3}$. Importantly, none of the papers considered by Bonner et al. (2000) deals with trading activity or market participation; the studies in their literature survey on incentive schemes consider relatively simple tasks such as recalling words or solving arithmetical problems with no risk or uncertainty involved. In contrast, Kohlmeyer and Drake (2009) find that in a financial decision-making context threshold a bonus scheme does not increase risktaking in new project selection relative to a linear bonus scheme. Our study focuses on trading, a simultaneously risky and effort-eliciting activity. So we conjecture that a threshold bonus scheme is likely to increase (relative to a linear bonus scheme) the level of effort exercised by traders, which increases their trading intensity.

Conjecture 1 Trading intensity is higher under the threshold than under the linear bonus scheme.

According to Heath, Larrick, and Wu (1999), threshold goals may serve as reference points. Thus, the trading performance should be evaluated in accordance with the value function of a corresponding reference point as suggested by prospect theory (Kahneman \& Tversky, 1979). Accordingly, outcomes below the goal are coded by a trader as losses and those above the goal as gains. Loss aversion and diminishing sensitivity result in high trading intensity and risk-seeking below the goal and low trading intensity and risk aversion above the goal. Thus, once the threshold is reached, the pressure to perform well decreases significantly and as a result trading intensity drops.

Conjecture 2 Once a bonus scheme threshold is met, trading intensity decreases.

In contrast to the above benefits of threshold bonus schemes, the behavioral literature suggests that the requirement to reach specific performance thresholds may lead to suboptimal decision making. Kohn (1993) writes: "Do rewards motivate people? Absolutely! They motivate people to get rewards." In other words, the threshold may itself become a target at the expense of the actual target, which is to make optimal trading decisions. Moreover, Bonner et al. (2000) and Bonner and Sprinkle (2002) find that incentives are less likely to improve performance in difficult tasks or in tasks where the gap between task difficulty and subjects' skill is substantial. Trading in the stock market is a difficult task, which requires significant mental effort to detect information related to future stock performance. Hence, we argue that while the threshold bonus scheme may induce higher

\footnotetext{
${ }^{3}$ Under linear schemes every piece of output is rewarded with an equal payment; in tournaments the winner gets all while the others get nothing; and under fixed-rate schemes the payment does not depend on performance.
} 
effort, it may fail to improve performance. Thus, their performance may suffer from excessive trading.

Conjecture 3 Under the threshold bonus scheme, traders harm their performance by trading more (even when transaction costs are zero).

The previous literature suggests that past market ${ }^{4}$ returns significantly affect investor behavior (Kim \& Nofsinger, 2007; Statman, Thorley \& Vonkink, 2006; Glaser \& Weber, 2009; Shi \& Wang, 2010). Moreover, high performance of specific stocks may catch investors' attention and result in higher trading activity in those stocks (Cooper, Dimitrov, \& Rau, 2001; Bae \& Wang, 2012). In our experiment subjects trade only one stock and if it performs well then they may expect higher future returns which would subsequently augment trading intensity, transaction frequency and transaction size. ${ }^{5}$ To assess the impact of the market conditions, we vary the stock profitability in our experiment (high vs. low profitability conditions). Under high profitability conditions it is relatively easy to earn money as average share price returns of the experimental stock are high, whereas under low profitability conditions returns are lower and only elaborated trading strategies may result in good performance.

Conjecture 4 Trading intensity is higher under favorable market conditions.

We employ a two (bonus scheme: linear vs. threshold) by two (session profitability: low vs. high) between-subject experimental design. The linear bonus scheme always pays a fixed percentage of the profit earned by traders as their bonus. The threshold bonus scheme is piecewise linear; it sets two explicit performance goals at which a higher bonus and a steeper performance-bonus relationship can be reached. In particular, under the high-profitability conditions the lower threshold is relatively easy to reach, whereas under the low-profitability conditions, the same threshold is relatively difficult to attain.

We report a set of interesting results. First, under the threshold bonus scheme the traders trade more intensively than under the linear one. Moreover, under the former scheme, trading intensity significantly depends on whether or not a threshold is reached. Trading

\footnotetext{
4

${ }^{5}$ In addition, it has been shown that traders credit themselves for success and positive performance, while attributing failures and negative performance to external factors such as bad luck or others' mistakes. This inevitably leads to overconfidence in trading skills as the self-attribution bias prevents investors from making an objective assessment of their abilities and the resulting performance (Daniel, Hirshleifer, \& Subrahmanyam, 1998; Gervais \& Odean, 2001).
} 
intensity declines once a threshold is met; this effect is especially strong for the higher threshold. Although the threshold bonus scheme leads to higher trading intensity, it fails to induce higher performance. Indeed, the quality of the investment decisions and the final performance are significantly lower under the threshold than under the linear scheme. In our experiment, trading was costless, so the lower returns earned under the threshold scheme cannot be explained by transaction costs. We argue that reaching a threshold may itself become a target at the expense of optimal trading decisions. Thus, bonuses may be detrimental for performance at least in comparison with linear compensation schemes.

The remainder of this paper is organized as follows. Section 2 describes the experimental design and provides a detailed description of the two bonus schemes. Section 3 presents the results, and Section 4 concludes.

\section{Experimental Design}

During fifty experimental trading rounds the participants in our experiment (whom we will call traders henceforth) acted as the employees of a trading company (see Appendix A for the experimental instructions). They bought and sold shares of a particular stock and were provided with technical and fundamental information about the company and the market (the past evolution of the share price, the company's past earnings, the analysts' earnings forecasts, and the evolution of the market index). All this information consists of real data on the US company Praxair, Inc. ${ }^{6}$ and on the US S\&P500 market index. The data processes were linearly rescaled and Praxair's name was substituted by a neutral company name so that the traders would not be able to identify the firm nor the time period. The information about changes in earnings and analysts' earnings forecasts was given every third trading round (since Praxair reports on a quarterly basis and the share price and market data are on a monthly basis). The stock did not pay dividends and we did not provide a bid-ask spread to make sure that transaction costs were zero. The traders were price takers and they were explicitly told in the instructions that their decisions did not influence stock price and other variables.

The traders started the first round without holding any shares but with an endowment of E\$500 (experimental dollars) in cash. At the beginning of every subsequent trading round,

\footnotetext{
${ }^{6}$ We chose a company for which information on the earnings, analysts' forecasts, and share price performance was available for at least ten years. Moreover, the share price process did not experience sharp ups-and-downs and was characterized by a period with a prolonged upward movement and a period with a lower trend.
} 
the traders received an additional $\mathrm{E} \$ 100$ in cash to ensure that they would have sufficient resources for trading. We thus enabled them to make investment decisions over the whole time span of the trading session. The total amount of cash received by each trader during the fifty rounds of the trading session was $\mathrm{E} \$ 5,400$.

Every round, traders chose how many stock shares to buy or sell (but short selling was not allowed). In each round, the traders had 15 seconds to make their investment decisions; pre-testing showed that this interval was sufficient to make trading decisions. If a trader did not react within the given time span, a new round started, the share holdings remained unchanged and the cash holdings increased with an additional endowment of $\mathrm{E} \$ 100$. At the end of every round, traders' cumulative performance was displayed; every trader could see only his or her own performance but not that of others.

The experiment was programmed using z-Tree software (Fischbacher, z-Tree: Zurich toolbox for ready-made economic experiments, 2007) and all the experimental sessions took place at Tilburg University, the Netherlands. The traders were undergraduate or graduate students (invited via the university website) who had previously indicated their interest in participating in paid experiments. A total of 123 students participated in the experiment: 64 females and 59 males, with an average age of 23 years.

\section{Bonus schemes}

At the beginning of the experiment, the traders were randomly assigned to one of two bonus schemes. Under the linear scheme, the traders always received 35\% of the total profit. Figure 1a shows the bonus paid under the linear scheme as a function of the total return earned at the end of fifty rounds.

[Insert Figure 1 and Table 1 around here]

Table 1 and Figure $1 \mathrm{~b}$ show the bonus paid under the threshold scheme. If the trader's total return at the end of the trading session under the threshold bonus scheme was between 0 and $25 \%$, she received $25 \%$ of the total profit. If the total return was between $25 \%$ and $45 \%$, she received $35 \%$, and if the total return exceeded $45 \%$, she received $45 \%$. Thus, the above two thresholds served as implicit performance targets for the traders.

Both linear and threshold bonus schemes reward positive performance but do not punish for negative returns as a trader is simply not paid any bonus if her total return is below zero. Here we follow the tradition held in industry where traders' punishment for negative 
performance is absence of bonus payment. Obviously, in cases of extreme losses traders would face a higher probability of being fired, but in the current study we do not consider employment incentives for traders to keep things simple.

Note also that under the linear scheme non-trading does not result in a reduction in the absolute amount paid as a bonus. In other words, if a trader considers the bonus earned to be sufficiently high and does not want to take further risks, she can sell all available shares and secure the bonus paid at the end of the trading session ${ }^{7}$. This strategy is not feasible under the threshold scheme if a trader is above a threshold. Because the trader receives additional cash at the beginning of every round, no trading decreases her total return (expressed as a percentage of the total cash received) and hence the part of the total profit she will receive as bonus.

The final bonus was determined only by the trader's performance at the end of fifty rounds and by the type of bonus scheme (linear or threshold). The final bonus was paid to the traders privately and in cash at the rate of 1 Euro for every E $\$ 50 .{ }^{8}$ Thus, only the total return achieved at the end of the fifty round trading session determined the amount of money traders took home after the experiment; none of the intermediate performance results directly affected the final payment.

\section{High and low share price returns}

At the beginning of the experiment, the traders were randomly assigned to one of two trading sessions that differed in terms of the average profitability of the traded stock. The stock-price process was more favorable in the "high stock return" (HighSR) session, with an average share price return of $2.35 \%$ per round. In the "low stock return" (LowSR) session, the average share price return was $0.82 \%$ per round. Table 2 compares the share price behavior in the HighSR and LowSR sessions; the average share price return session was 2.8 times larger in the HighSR than that in the LowSR session. During the HighSR session the share price increased by $183.39 \%$, whereas the increase was merely $24.12 \%$ in the LowSR session. In other words, $\mathrm{E} \$ 1$ invested in the stock in the first trading round would be worth $\mathrm{E} \$ 2.83$ at the end of the HighSR session but only E\$1.24 at the end of the LowSR session.

\footnotetext{
${ }^{7}$ Under the linear scheme, Bonus $=$ Profit $\mathrm{x} 35 \%$, where Profit is the difference between the cash and stock holdings and the investment received. Under the threshold scheme, Bonus = Profit $\mathrm{x} \mathrm{K \%}$, where $\mathrm{K}$ depends on the total return earned.

${ }^{8}$ To ensure that all participants had a fair chance on a similar payoff, the bonus schemes were created in such a way that a random trading pattern would yield about the same payoff.
} 
[Insert Table 2 around here]

Taking bonus scheme and profitability conditions together, the traders were randomly assigned to one of four treatments: linear bonus scheme and low stock return session (LinLow); linear bonus scheme and high stock return session (LinHigh); threshold bonus scheme and low stock return session (ThresLow); and threshold bonus scheme and high stock return session (ThresHigh; see Table 3). We performed between-subject comparisons of the four treatments to identify how bonus scheme and share price profitability influence the trading behavior of traders.

[Insert Table 3 around here]

\section{Results}

We structure the presentation of our results as follows: we start by analyzing trading intensity, which will subsequently be dissected into two dimensions (transaction frequency and transaction size). We then analyze the impact of bonus schemes, and of the profitability of the traded stock on trading activity. Next, we turn to a multivariate analysis of trading intensity which controls for the impact of trading information and traders' characteristics. Finally, we focus on traders' performance and perform robustness checks.

\subsection{Trading intensity}

In every round, we calculate for each trader the maximum number of shares she can buy and sell. The maximum number for sale is the number of shares the trader holds as short selling is not allowed; the maximum number she can buy equals her cash holdings divided by the current share price. To test conjecture 1, we create a dependent variable called Trading Intensity, which is defined as the sum of two ratios: the number of shares bought divided by the maximum number of shares that could be bought plus the number of shares sold divided by the maximum number of shares that could be sold:

Trading Intensity $=\frac{\text { Number of shares bought }}{\text { Max. number of shares could be bought }}+\frac{\text { Number of shares sold }}{\text { Max. number of shares could be sold }}$

If in the current round a trader neither buys nor sells shares then the Trading Intensity is zero (see Appendix B for detailed definitions of the variables). We assume that trading intensity reflects traders' beliefs about future share price development. For example, if the trader strongly believes that the share price will go up in the next round, she is likely to buy 
as many shares as she can in the current round and her trading intensity would equal $100 \%$. The trader would sell all her shares if she expects the share price to decrease in the next round. When the trader expects the share price to rise or fall with equal probability, then she will neither buy nor sell shares and will wait until the next round when more information arrives ${ }^{9}$.

Table 4 and Figure 2 compare the four treatments in terms of average Trading Intensity. On average, $51.59 \%$ of the available shares were traded every round. There is a significant difference in average trading intensity under the linear and threshold bonus schemes (column 2 of Table 4, Panel A), and in the HighSR and LowSR sessions (row 2 of Table 4, Panel A). In accordance with conjecture 1, the more trading occurred under the threshold than under the linear bonus scheme, with the difference amounting to $4.60 \%(\mathrm{t}=$ 4.15, $\mathrm{p}<0.01)$. Moreover, this difference stays almost the same when the LowSR and HighSR sessions are considered separately: $4.62 \%(\mathrm{t}=2.92, \mathrm{p}<0.01)$ in the LowSR session and $4.28 \%(\mathrm{t}=2.77, \mathrm{p}<0.05)$ in the HighSR session (bottom row of Table 4, Panel A). These results confirm Conjecture 1 in that the trading intensity is significantly higher under the threshold scheme than under the linear one.

In accordance with conjecture 4, trading intensity in the HighSR session was significantly higher than in the LowSR session. Indeed, the difference in average trading intensity between the HighSR and LowSR sessions is $7.03 \%(t=6.33, \mathrm{p}<0.01)$. Moreover, this difference between the profitability conditions does not depend on the bonus scheme: the difference amounts to 7.09\% $(\mathrm{t}=4.46, \mathrm{p}<0.01)$ and $6.75 \%(\mathrm{t}=4.36, \mathrm{p}<0.01)$ for the linear and the threshold bonus schemes, respectively. An ANOVA also reveals no significant interactions between type of bonus scheme and stock profitability conditions (Table 4, Panel B).

Thus, we conclude that the threshold bonus scheme induces higher trading intensity and that higher profitability opportunities also lead to more intensive trading.

[Insert Table 4 and Figure 2 around here]

To investigate further what drives the differences in trading intensity between the treatments, we partition Trading Intensity into Transaction Frequency and Transaction Size. The former is a dummy variable that equals 1 if a trader buys or sells shares in the current

\footnotetext{
${ }^{9}$ In real life, investors have other reasons to trade, including liquidity needs and tax considerations. However, these issues are not relevant in the present experimental setting.
} 
round (i.e., if a transaction takes place) and 0 otherwise. Transaction Size is defined only for those rounds in which a trader buys or sells shares (i.e., when Transaction Frequency equals 1).

Transaction Frequency $=\left\{\begin{array}{l}1, \text { when a participant buys or sells any number of shares } \\ 0, \text { otherwise }\end{array}\right.$

Transaction Size $=\left\{\begin{array}{l}\frac{\text { Number of shares bought }}{\text { Max. number of shares could be bought }}, \text { when a participant buys shares } \\ \frac{\text { Number of shares sold }}{\text { Max. number of shares could be sold }}, \text { when a participant sells shares }\end{array}\right.$

Table 5 and Figure 3 compare the four treatments in terms of average Transaction Frequency per trading session (of fifty rounds). The traders sold and purchased shares in more than $79 \%$ of the trading rounds. . While there was no difference in transaction frequency between high and low profitability sessions, there was a clear difference under the linear and threshold schemes. The transaction frequency is significantly higher (by $6.88 \%$ with $t=6.66$ and $p<0.01$ ) under the threshold than under the linear scheme (column 2 of Table 5, Panel A). The difference in transaction frequency under the two schemes provides additional support for conjecture 1. Next, we compare transaction frequency between schemes separately in the LowSR session (treatments LinLow and ThresLow) and the HighSR session (treatments LinHigh and ThresHigh). In both sessions, transaction frequency was higher in the threshold than the linear scheme (LowSR: 9.51\%, $\mathrm{t}=6.29, \mathrm{p}<0.01$, column 3 of Table 5, Panel A; HighSR: 4.60\%, t = 3.26, p < 0.01, column 4 of Table 5, Panel A). Since the information set was the same under both bonus schemes, the higher transaction frequency was presumably driven by the pressure to reach the implicit goals under the threshold scheme. This pressure seems to be especially high when the opportunities for good performance are limited, i.e., in the LowSR session. An ANOVA analysis (Table 5, Panel B) confirms a significant interaction effect between bonus-scheme type and stock profitability ( $\mathrm{p}$ $<0.05)$. Figure 3 presents a graphical analysis of the transaction frequency under the four treatments. Thus, Table 5 and Figure 3 combined provide evidence supporting conjecture 1 , namely that the threshold scheme induces more aggressive trading behavior in the form of higher transaction frequency. Moreover, contrary to conjecture 4, Transaction Frequency was not affected by profitability conditions.

[Insert Table 5 and Figure 3 around here]

Table 6 and Figure 4 present the Transaction Size by treatment. On average, traders traded around $65.19 \%$ of the number of shares available (conditional on a transaction taking 
place). We unveil that transaction size does not depend on the type of bonus scheme. However, the average Transaction Size is positively related to the profitability of the trading sessions. In the LowSR session trading amounted to $60.46 \%$ of the available shares, which is $8.81 \%$ less than in the HighSR session $(69.27 \% ; \mathrm{t}=7.91, \mathrm{p}<0.01)$. The difference in Transaction Size between HighSR and LowSR session shows up for both bonus schemes; it amounts to $7.31 \%(\mathrm{t}=4.51, \mathrm{p}<0.01)$ and $10.14 \%(\mathrm{t}=6.65, \mathrm{p}<0.01)$ for the linear and threshold scheme, respectively. To sum up, under favorable profitability conditions the traders invested a higher percentage of their wealth in the stock. This result supports conjecture 4, suggesting that we primarily find support for conjecture 4 in terms of transaction size rather than frequency.

\section{[Insert Table 6 and Figure 4 around here]}

To conclude this section, we find that in our experiment trading activity was significantly higher under the threshold than under the linear scheme in terms of average share turnover and average transaction frequency. By extension, the results suggest that increased trading frequency may be caused not only by traders' overconfidence (Barber \& Odean, 2001) or past individual performance (Grinblatt \& Keloharju 2001; Statman, Thorley, \& Vorkink, 2006; Glaser \& Weber, 2009; Nicolosi, Peng, \& Zhu, 2009) but also by the type of bonus scheme. In contrast, the average transaction size was affected only by profitability conditions, but not by the type of bonus scheme.

\subsection{Trading intensity around bonus thresholds}

To investigate how trading behavior changes around the thresholds and to test conjecture 2, we plot the average transaction frequency ${ }^{10}$ against the total return earned by the traders. We divide the total return values into intervals of five percentage points, starting from a negative performance of $-5 \%$. Then, we calculate the mean and standard deviation of the variable Transaction Frequency under the linear and threshold schemes for each interval. Finally, we depict these means and their $95 \%$ confidence intervals by performance interval to obtain a histogram of probabilities that transactions are made for different total returns (Figure 5). Figure 5a shows, as expected, that there are no significant differences between the average transaction frequencies across the total return intervals ${ }^{11}$ under the linear scheme.

\footnotetext{
${ }^{10}$ We use the average transaction frequency instead of the trading intensity because we showed in the previous section that the transaction frequency is affected by the type of bonus scheme but not by the profitability conditions.

${ }^{11}$ The $95 \%$ confidence intervals of the transaction frequency are especially wide for very high (above $70 \%$ ) and very low (below $-5 \%$ ) performance because of the small number of observations.
} 
Under the threshold scheme the behavior changes significantly once the thresholds are met (Figure 5b). In accordance with conjecture 2, after reaching a threshold, the traders made significantly fewer transactions. Interestingly, the mean number of transactions does not drop immediately after the threshold (i.e. in the [25\%, 30\%], [45\%, 50\%] intervals), but in the adjacent intervals $([30 \%, 35 \%],[50 \% 55 \%])$. This implies that the traders applied a 5\% safety margin above the threshold, before they decreased their transaction frequency ${ }^{12}$. The average transaction frequency is 0.83 on the whole range of the total return interval [-5\%, $70 \%]$. Once the $45 \%$ threshold is passed, this frequency drops to $0.57(\mathrm{t}=5.74, \mathrm{p}<0.01)$ in the $[50 \%, 55 \%]$ interval. For the $25 \%$ threshold, we observe a similar effect: the transaction frequency decreases from 0.83 in $[-5 \%, 70 \%]$ to 0.76 in the $[30 \%, 35 \%]$ interval. Although the decrease is clearly significant $(t=2.38, \mathrm{p}<0.05)$, it is less pronounced, probably because of the incentives created by the next performance threshold (at $45 \%$ ).

[Insert Figure 5 around here]

\subsection{Trading intensity in a multivariate setting.}

We analyze the influence of bonus schemes and stock-price profitability on trading behavior by investigating the transaction intensity, frequency, and size in a multivariate setting:

$$
\begin{array}{r}
\mathrm{Y}=\alpha+\beta_{1} \text { ThresBS }+\beta_{2} \text { HighSR }+\beta_{3}{\text { ThresBS } \times \text { HighSR }+\sum \gamma_{\mathrm{i}} \text { Threshold Variable }_{\mathrm{i}}}+\sum \theta_{\mathrm{j}} \text { Information Variable }_{\mathrm{j}}+\sum \delta_{\mathrm{k}} \text { Trader's }_{\text {Sharacteristics }}+\varepsilon
\end{array}
$$

In the equation above, $\mathrm{Y}$ stands respectively for Trading Intensity, Transaction Frequency, and Transaction Size. As the main explanatory variables we employ the type of bonus scheme (the dummy variable ThresBS), the type of stock profitability of the trading session (the dummy variable HighSR), and their interaction term (ThresBS $\times$ HighSR) to capture the effects of the bonus scheme and stock-return profitability on the various

\footnotetext{
${ }^{12}$ As previously noted, under the threshold scheme, new endowments deteriorate the returns. For example: a trader's total return equals $30 \%$. After selling the shares she has $130 \%$ of her investment in cash (e.g. E\$700) at round $t$. As of the next round $(t+1)$, she adopts a passive strategy and no longer invests; she receives an additional investment of $\mathrm{E} \$ 100$, such that her total return is $30 \% * \mathrm{E} \$ 700 /(\mathrm{E} \$ 700+\mathrm{E} \$ 100)=26.25 \%<30 \%$. At $(\mathrm{t}+2)$, the return is $30 \% * \mathrm{E} \$ 700 /(\mathrm{E} \$ 700+\mathrm{E} \$ 200)=23.33 \%$. Under the threshold bonus scheme, the bonus depends on the total return earned. If the trading session would end at ( $t+1)$, she would receive a bonus of $\mathbf{3 5 \%}$ or $\mathbf{E} \mathbf{\$ 2 4 5}$ but if the end is at $(t+2)$, she would only receive a bonus of $\mathbf{2 5 \%}$ or $\mathbf{E} \mathbf{\$ 1 7 5}$. Thus, a passive strategy of no trading can erode the bonus. Hence, to consolidate their positions, traders under the threshold scheme better only reduce their trading activity after exceeding a threshold with a safety margin (which is here empirically 5\%). In contrast, under linear bonus scheme, the bonus depends only on the additional money earned, so the trader's bonus equals $35 \% \cdot \mathrm{E} \$ 700=\mathrm{E} \$ 245$.
} 
dimensions of trading activity. To further test conjecture 2 we include several threshold variables, namely dummies for the post-threshold return intervals, Return [30\%, 35\%] and Return [50\%, 55\%], and their interaction terms with ThresBS. For example, Return [30\%, $35 \%$ ] equals 1 if the total return earned by a trader so far falls into the interval [30\%,35\%]. To match the traders' strategy we use a safety margin of 5\% to determine the above intervals. In the above equation, we add as controls the information variables (most recent stock return prior to a trade, the market return, the earnings, and the earnings' forecasts), and traders' characteristics (such as risk aversion, the average percentage of trader's total wealth invested in stock, her total return to date, and the change in her total return to date since the last round) (see appendix B for definitions).

To control for the information available to traders, we include the most recent share price return at the time of the transaction, the market return, earnings announcements, and analysts' earnings forecasts. Moreover, we also control for traders' characteristics, such as the total return earned by a trader from the beginning of the trading session to the current round (Total Return to Date) and change in her total return since the last round (Change in Total Return). Because higher risk aversion is likely to decrease trading intensity ${ }^{13}$, we include in the regression analysis a measure of traders' risk attitude: the average percentage of a trader's wealth invested in the stock (Average \% in Stock). This variable is a proxy for traders' risk attitudes since more risk tolerant traders are more likely to invest more into the risky asset ${ }^{14}$.

\section{Trading intensity, propensity, and size}

For the dependent variable Trading Intensity, we estimate a Tobit model, because short selling and borrowing cash were not allowed in our experimental setting. Models (1) and (2) of Table 7 estimate the influence of the type of bonus scheme and stock profitability on the trading intensity. We confirm that under the threshold scheme a higher percentage of shares is traded: in models (1) and (2) the coefficient on ThresBS variable is positive and significant at $1 \%$ level. The thresholds under this scheme negatively affect the trading intensity once they are achieved with a sufficient safety margin (see model (2)). The coefficients on the interaction terms Return [30\%, 35\%] x ThresBS, and Return [50\%, 55\%] x ThresBS are all negative and significant $(\mathrm{t}=2.10, \mathrm{p}<0.05$ and $\mathrm{t}=2.86, \mathrm{p}<0.01)$. Moreover, trading

\footnotetext{
${ }^{13}$ Odean (1998) and Hirshleifer and Luo (2001) mainly consider the effect of overconfidence on trading behavior. However, after controlling for overconfidence it can be shown that in their models trading volume decreases with greater risk aversion.

${ }^{14}$ As an alternative control for risk aversion we also used Holt and Laury $(2002,2005)$ measure, which did not influence our main results.
} 
intensity decreases further once the second $45 \%$ threshold is passed: the coefficient on Return $[50 \%, 55 \%] \times$ ThresBS is almost twice as large in absolute value as the coefficient on Return $[30 \%, 35 \%] \times$ ThresBS. Note that the same intervals under the linear scheme do not have any significant influence on the trading intensity (Return [30\%, 35\%] and Return [50\%, 55\%] are not significant).

\section{[Insert Table 7 around here]}

To further assess how bonus-scheme types and profitability conditions influence trading activity, we dissect trading intensity into the propensity to trade (transaction frequency) (logit models (3) and (4) of Table 7) and transaction size (models (5) and (6). The ThresBS dummy is positive and significant (for models (3) and (4), the p-values are below $1 \%$ ), suggesting that the traders are more likely to trade under the threshold than under the linear scheme. We confirm that trading frequency significantly decreases when a threshold is passed with a 5\% safety margin: the coefficients on Return [30\%, 35\%] x ThresBS, and Return $[50 \%, 55 \%] \times$ ThresBS are both negative and significant at the 5\% level $(\mathrm{t}=2.60, \mathrm{p}<$ 0.01 and $\mathrm{t}=2.41, \mathrm{p}<0.05)$. We also find a significantly negative interaction effect between bonus scheme type and profitability conditions: the coefficient on ThresBS x HighSR is negative and significant (for model (3) with $\mathrm{t}=2.10, \mathrm{p}<0.05$ ). So, whereas the probability to make a transaction was higher under the threshold than under linear scheme, this effect was moderated under high profitability conditions (see also Fig. 3). The combined effect of threshold scheme and high profitability conditions is significantly positive $\left(\chi^{2}=11.80, \mathrm{p}<\right.$ 0.01). However, this effect disappears once we include the thresholds in the regression in model (4).

Tobit regressions with Transaction Size as a dependent variable are presented in Table 7 (models (5) and (6)). Surprisingly, the threshold scheme does not affect the transaction size: the ThresBS coefficient is not significant in models (5) and (6). However, we find a significantly positive interaction effect between ThresBS and HighSR: the coefficient on Thresh $\mathrm{x}$ HighSR is positive and significant at the 5\% level (see also Fig.4). Thus, the threshold bonus scheme increases transaction size only in the HighSR session. Finally, whereas the coefficient on Return [30\%, 35\%] x ThresBS becomes insignificant the lower threshold of $25 \%$ has no impact on the transaction size, the transaction size is still influenced by the $45 \%$ threshold. The coefficient on Return [50\%, 55\%] x ThresBS is negative and significant $(\mathrm{t}=1.96, \mathrm{p}=0.05)$. 


\section{The impact of information and traders' characteristics on trading intensity}

While Return to Date does not affect trading intensity and its components (Transaction Frequency and Transaction Size), Change in Total Return influences traders' propensity to trade (see models (1)-(2) and (5)-(6)). More specifically, if the total return earned by traders' in the current round in higher than in the previous one, then trading intensity decreases mostly because traders start trading smaller stakes: the coefficient on Change in Total Return is negative and significant at the 5\% level - models (1)-(2) and (5)-(6). This result is in line with predictions from prospect theory that people tend to become more (less) risk averse when their performance is above (below) their reference point (the previous round performance in our case).

The share of a trader's wealth invested in stocks (Average \% in Stock), which could be seen as a proxy for risk tolerance in the investment domain, is positively related to trading intensity (both transaction frequency and size). So traders with higher risk tolerance traded more frequently and at higher stakes: the coefficient on Average \% in Stock is positive and significant for all models (1)-(6).

The influence of the information variables is in line with our expectations. It seems that the participants were using technical rather fundamental information: Stock Return and Market Return have a positive and strongly significant effect on trading intensity and its two dimensions (frequency and size), whereas earnings and their forecast did not affect trading behavior.

\subsection{Performance}

In the previous sections, we have shown that under the threshold bonus scheme traders traded more actively than under the linear one. On the one hand, there are reasons why one could expect that higher trading intensity under the threshold scheme does not necessarily result in poor performance. For example, the desire to earn more money and to reach thresholds may make people think harder, estimate market opportunities better, and finally make better decisions. On the other hand, increased transaction frequency may result in lower performance due to higher transaction costs (Barber \& Odean, 2000, 2001), mediocre stock picking (Shi \& Wang, 2010), or inferior market timing (Kim \& Nofsinger, 2007). Our experimental market contains only one stock (i.e., does not allow for stock picking) and does not involve any transaction costs. Hence, our set-up enables us to study the effect of the 
bonus scheme type on market timing. To this effect, we compare the quality of the trading decisions under the different bonus schemes.

To maximize their final personal payoff, the traders needed to maximize their return at the end of the trading session of 50 rounds. Since the share did not pay dividends and short selling was not possible in our experiment, the strategy "buy low and sell high" was the only one that could provide positive returns. Traders could try to implement this strategy by buying stocks before the share price went up and by selling them before the share price went down. To estimate the quality of the trading decisions, we calculate the difference in the share price returns after stock share were bought and sold. If this difference is positive on average, the traders made good investments and on average correctly predicted/guessed the share price movements.

We calculate the difference in the returns as follows. First, we calculate an average purchase-based return. For all the rounds in which a trader has bought shares, we calculate an average next-round stock return, i.e., we sum all the next-round stock-price returns for the rounds in which a trader bought shares and divide that sum by the total number of rounds in which shares were bought. Then, using the same procedure, we compute an average salebased stock-price return and subtract it from the average purchase-based stock return. The deduction we call Return Difference.

Return Difference $^{i}=\sum_{\mathrm{t}}\left(\right.$ Stock Return $\left._{\mathrm{T}+1} \mid \mathrm{B}_{\mathrm{t}}^{\mathrm{i}}=1\right)-\sum_{\mathrm{t}}\left(\right.$ Stock Return $\left._{\mathrm{t}+1} \mid \mathrm{B}_{\mathrm{t}}^{\mathrm{i}}=0\right)$

where $B_{t}^{i}$ is 1 when trader $i$ buys shares and 0 when she sells shares. Conjecture 3 states that under the threshold scheme traders make poorer investment decisions because of the pressure to reach the targets. This effect must be especially prominent in the LowSR session when it is more difficult to reach the thresholds and the pressure to perform higher. Table 8 compares the four treatments in terms of average Return Difference.

[Insert Table 8 around here]

Table 8 shows that on average traders make significantly poorer investment decisions under the threshold scheme than under the linear scheme (column 2 of Table 8). The average difference in share price returns after buying and selling shares is $1.58 \%$ under the linear scheme, whereas it is only $0.36 \%$ under the threshold scheme. The difference between the two values is positive $(1.22 \%)$ and significant $(\mathrm{t}=2.69, \mathrm{p}<0.01)$. This pattern holds in both profitability sessions: in the LowSR session the difference between the average share price 
purchase-based and sale-based returns is $1.42 \%$ higher under the linear than under the threshold bonus scheme $(t=2.00, p<0.05)$. In the HighSR session, the average Return Difference under the linear bonus scheme exceeds the one under the threshold bonus scheme by only $0.98 \%$ and this difference is weakly significant $(t=1.74, p<0.10)$. Thus, under the threshold scheme, the traders did not make better investment decisions than under the linear scheme. On the contrary, their attention to the implicit targets and the pressure to perform well has made them worse investors, which supports conjecture 3. As a robustness check, we calculated a volume-based difference in returns whereby the next round return after a purchase (sale) is multiplied by the percentage of shares bought (sold) and conclude that the results remain virtually unchanged (not reported here).

The difference between the average purchase-based and sale-based returns in the LowSR session is $1.58 \%$ and in the HighSR session is $0.43 \%$ (Row 2 of Table 8). This implies that the two profitability conditions are statistically distinct in terms of the quality of traders' investment decisions $(\mathrm{t}=2.50, \mathrm{p}<0.05)$. In the LowSR session, the traders made better decisions: they bought shares before the share price went up and they sold shares before the share price went down. Thus, when earning money by trading was relatively difficult, the traders may have collected more information about the relationships between the share price and the market returns, earnings, and earnings forecasts, applied more effort to understand those relationships, and they finally performed better. In contrast, under high profitability conditions, they seemed to merely chase high returns. Previous research has shown similar patterns in investors' behavior during bull and bear markets: Japanese and Chinese investors made inferior investment decisions during bull markets in comparison with bear markets due to poorer market timing and stock selection (Kim \& Nofsinger, 2007; Shi \& Wang, 2010). A comparable result was found for mutual fund investors across the business cycle (Cederburg, 2008).

The above results are based on the returns calculated after the trade. We now evaluate the actual average performance obtained over the entire trading session. Did traders under the threshold scheme do better? Were they able to exploit the different share price profitability conditions? To answer these questions we compare the final returns earned by the traders at the end of the trading session of 50 rounds between the four treatments (see Table 9). We use the Final Total Return variable which is defined as Total Return to Date at the $50^{\text {th }}$ round. If we pool the observations from the two profitability sessions, the difference in final returns between the two bonus schemes is insignificant (column 2 Table 9). In the LowSR session 
(column 3 Table 9), the average return at the end of $50^{\text {th }}$ round under the linear scheme equals $14.70 \%$, which is significantly higher (difference $=5.78 \%, t=1.84, p<0.10$ ) than the Final Total Return under the threshold bonus scheme (8.92\%). In contrast, this difference becomes insignificant in the HighSR session, when it was comparatively easy to earn money: the average final returns are $35.47 \%$ and $34.64 \%$ respectively under the threshold and linear bonus schemes. Thus, it seems that the pressure put on the traders to perform well may have distracted them from efficient information collection under the threshold scheme, whereas in the HighSR session they simply chased the performance wave under both bonus schemes.

[Insert Table 9 around here]

As expected, traders' returns at the end of $50^{\text {th }}$ round are significantly influenced by the profitability conditions. The average returns earned at the end of the LowSR and HighSR sessions are $11.86 \%$ and $35.07 \%$ respectively (row 2, Table 9); thus, their difference equals $23.21 \%$ and is statistically significant $(\mathrm{t}=8.74, \mathrm{p}<0.01)$. Under both bonus schemes this result remains significant. It should be noted that in the setup of this realistic experiment, both the profitability conditions and the bonus schemes have an impact on the total returns and hence the traders' bonus. While the share price and market evolution cannot significantly be influenced by traders or their employers, the traders' compensation schemes are nevertheless under the direct control of the companies.

\subsection{Robustness checks}

The performance near the end of the trading sessions contains more noise because the traders traded less at the end of the trading session. As a robustness check, we compare the average returns earned by the traders in the second half of the trading session, i.e., at the end of the $25^{\text {th }}$ round and later. Table 10 demonstrates that the results are consistent with those described in the previous section; the significance levels are much higher because of the increased number of observations.

To investigate whether or not the poorer performance under the threshold scheme is driven by lower risk-taking, we compare the average share of wealth invested in the stock for each of the four treatments. We find no difference between the average shares of wealth invested in the stock by type of bonus scheme (see Table 11). Thus, under the threshold scheme, the traders perform worse because they make poorer decisions, and their inferior performance does not follow from a difference in risk tolerance. 


\section{Conclusion}

To study the impact of different types of bonus schemes on the trading intensity of individual traders, we set up an experimental market in which traders sell and buy shares without transaction costs. The traders are price takers and are provided with fundamental and technical information (evolution of the market index, past share price evolution, realized earnings, and analysts' earnings forecasts). We trade off a basic linear bonus scheme against a threshold bonus scheme, both of which reflect the practice in investment banks and brokerage houses.

A first solid finding is that the threshold bonus scheme induces a higher trading intensity than a linear bonus scheme. When dissecting trading intensity into two dimensions, transaction frequency and transaction size, we document that the threshold scheme does indeed induce more aggressive trading behavior in the form of higher transaction frequency, but that the transaction size does not depend on the type of bonus scheme.

We also examine how the context of high and low profitability conditions (periods with higher and lower average share price returns) affects trading intensity. High profitability leads to a higher trading intensity only under the threshold bonus scheme, which is mainly explained by the execution of larger transactions. Considering four treatments consisting of the combination of types of bonus scheme and profitability conditions, we conclude that a threshold scheme induces frequent trading and trading at higher stakes, especially in trading sessions with high profitability conditions.

After reaching a return threshold that translates into a higher bonus, traders make significantly fewer transactions. Interestingly, the mean number of transactions does not drop immediately after the threshold, but in the next intervals, which implies that traders apply a $5 \%$ safety margin above the threshold before they decrease their transaction frequency.

To estimate the quality of the trading decisions, we examine the difference in the share price returns after the traders bought and sold shares as well as their overall performance over the whole trading session. If these differences are positive on average, the traders make good investments and on average correctly predict/guess the share price 
movements. We find that the traders make significantly poorer investment decisions under the threshold than under the linear bonus scheme. This effect is especially pronounced when earning money by trading is relatively difficult (in trading sessions with lower profitability conditions). Then, the traders seem to collect more information about the relationships between the share price and the market returns, earnings, and earnings forecasts, apply more effort to understand those relationships, and finally perform better under the linear bonus scheme, whereas under the threshold bonus scheme they seem to focus merely on reaching and maintaining threshold returns. Thus, we show that bonuses may be detrimental for performance at least when threshold and linear compensation schemes are compared. 


\section{References}

Bae, KH. \& Wang, W. 2012. What's in a "China" Name? A Test of Investor Attention Hypothesis. Financial Management 41: 429-455

Barber, B. \& T. Odean. 2000. Trading is hazardous to your wealth: The common stock investment performance of individual investors. Journal of Finance 55: 773-806.

Barber, B. \& T. Odean. 2001. Boys will be boys: Gender, overconfidence, and common stock investment. Quarterly Journal of Economics 116: 261-292.

Bebchuk, L. \& J. Fried. 2004. Pay without performance: The unfulfilled promise of executive compensation. Harvard University Press. Cambridge, Massachusetts, and London, England.

Bonner, S., R. Hastie, G. Sprinkle, \& M. Young. 2000. A review of the effects of financial incentives on performance in laboratory tasks: Implications for management accounting. Journal of Management Accounting Research 12: 19-64.

Bonner, S. \& G. Sprinkle. 2002. The effects of monetary incentives on effort and task performance: Theories, evidence, and a framework for research. Accounting, Organizations and Society 27: 303-345.

Cederburg, S. 2008. Mutual fund investor behavior across business cycle. Working paper. University of Iowa.

Chevalier, J. \& G. Ellison. 1997. Risk taking by mutual funds as a response to incentives. Journal of Political Economy 105: 1167-1200.

Cooper, M., Dimitrov, O., \& Rau, R., 2001. A rose.com by any name. Journal of Finance 56: 2371-2388.

Coval, J.D. \& T. Shumway. 2005. Do behavioral biases affect prices? Journal of Finance 60: $1-34$.

Daniel, K., D. Hirshleifer, \& A. Subrahmanyam. 1998. Investor psychology and security market under- and overreactions. Journal of Finance 53: 1839-1885.

Farnsworth, H., \& J. Taylor. 2006. Evidence on the compensation of portfolio managers. Journal of Financial Research 29: 305-324.

Fischbacher, U. 2007. z-Tree: Zurich Toolbox for Ready-made Economic Experiments. Experimental Economics 10: 171-178.

Garvey, R. \& F. Wu. 2010. Payday effect: An examination of trader behavior within evaluation periods. Journal of Behavioral Finance 11: 114-128.

Geithner, T. 2009 (10 June). Statement by Treasury Secretary Tim Geithner on Compensation. Washington D.C. U.S. Department of the Treasury.

Gervais., S. \& T. Odean. 2001. Learning to be overconfident. Review of Financial Studies 14: $1-27$.

Glaser, M. \& M. Weber. 2009. Which past returns affect trading volume? Journal of Financial Markets 12: 1-31. 
Grinblatt, M. \& M. Keloharju. 2001. What Makes Investors Trade? Journal of Finance 56: 589-616.

Heath, C., R. Larrick, \& G. Wu. 1999. Goals as reference points. Cognitive Psychology 38: 79-109.

Hirshleifer, D. \& G.Y. Luo. 2001. On the survival of overconfident traders in a competitive securities market. Journal of Financial Markets 4: 73-84.

Holt, C. \& S. Laury. 2002. Risk aversion and incentive effects. American Economic Review 92: $1644-1655$.

Holt, C. \& S. Laury. 2005. Risk aversion and incentive effects: New data without order effects. American Economic Review 95: 902-904.

Kahneman D. \& A. Tversky. 1979. Prospect theory: An analysis of decision under risk. Econometrica 47: 263-292.

Kempf, A., S. Ruenzi, \& T. Thiele. 2009. Employment risk, compensation incentives, and managerial risk taking: Evidence from the mutual fund industry. Journal of Financial Economics 92: 92-108.

Kim, K. \& J. Nofsinger. 2007. The behavior of Japanese individual investors during bull and bear markets. Journal of Behavioral Finance 8: 138-153

Kohlmeyer, J. \& Drake, A. 2009. Risk-taking in new project selection: Can bonus incentives overcome past performance history? AAA 2009 Management Accounting Section (MAS) Meeting paper.

Kohn, A. 1993. Why incentive plans cannot work. Harvard Business Review (Sept.-Oct), 5463.

Liu Y., C. Tsai, M. Wang, \& N. Zhu. 2010. Prior Consequences and Subsequent Risk Taking: New Field Evidence from the Taiwan Futures Exchange. Management Science 56: 606-620.

Nicolosi G., L. Peng, \& N. Zhu. 2009. Do individual investors learn from their trading experience? Journal of Financial Markets 12: 317-336.

Odean, T. 1998. Volume, volatility, price, and profit when all traders are above average. Journal of Finance 53: 1887-1934.

Shi Z. \& N. Wang. 2010. Don't confuse brains with a bull market: Attribution bias, market condition, and trading behavior of individual investors. Working paper.

Statman, M., S. Thorley, \& K. Vorkink. 2006. Investor overconfidence and trading volume. The Review of Financial Studies 19: 1531-1565. 


\section{Figure 1 Payoffs under linear and threshold bonus schemes}

Figure 1 shows the bonus paid under (1a) the linear and (1b) the threshold bonus schemes as a function of the total return earned at the end of the 50-round trading session. The total investment (the sum of the periodical endowments) at the end of the 50 rounds is $\mathrm{E} \$ 5,400$.

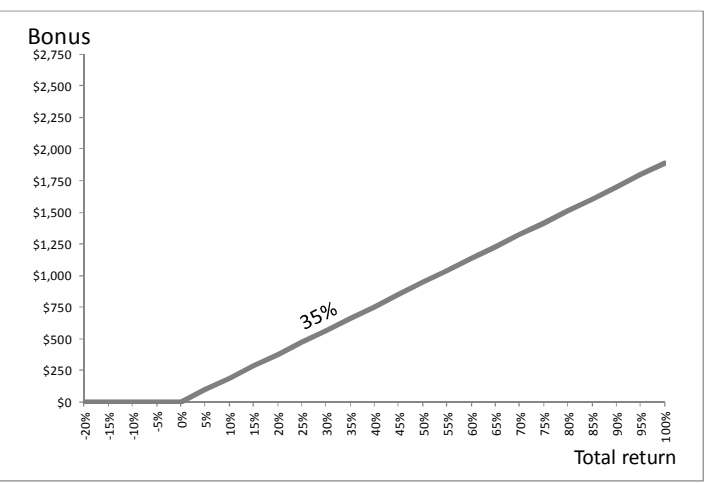

a. Linear bonus scheme

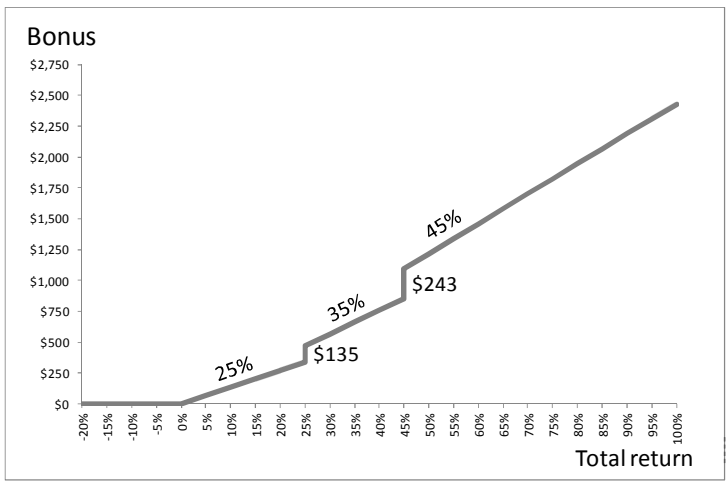

b. Threshold bonus scheme 


\section{Figure 2 Trading Intensity by bonus scheme and profitability treatments}

Figure 2 shows the average values of Trading Intensity in the four treatments (LinLow, ThresLow, LinHigh, and ThresHigh). Trading Intensity equals the number of shares bought divided by the maximum number that could be bought plus the number of shares sold divided by the maximum number that could be sold. Trading Intensity equals zero if a trader does not trade in the current round.

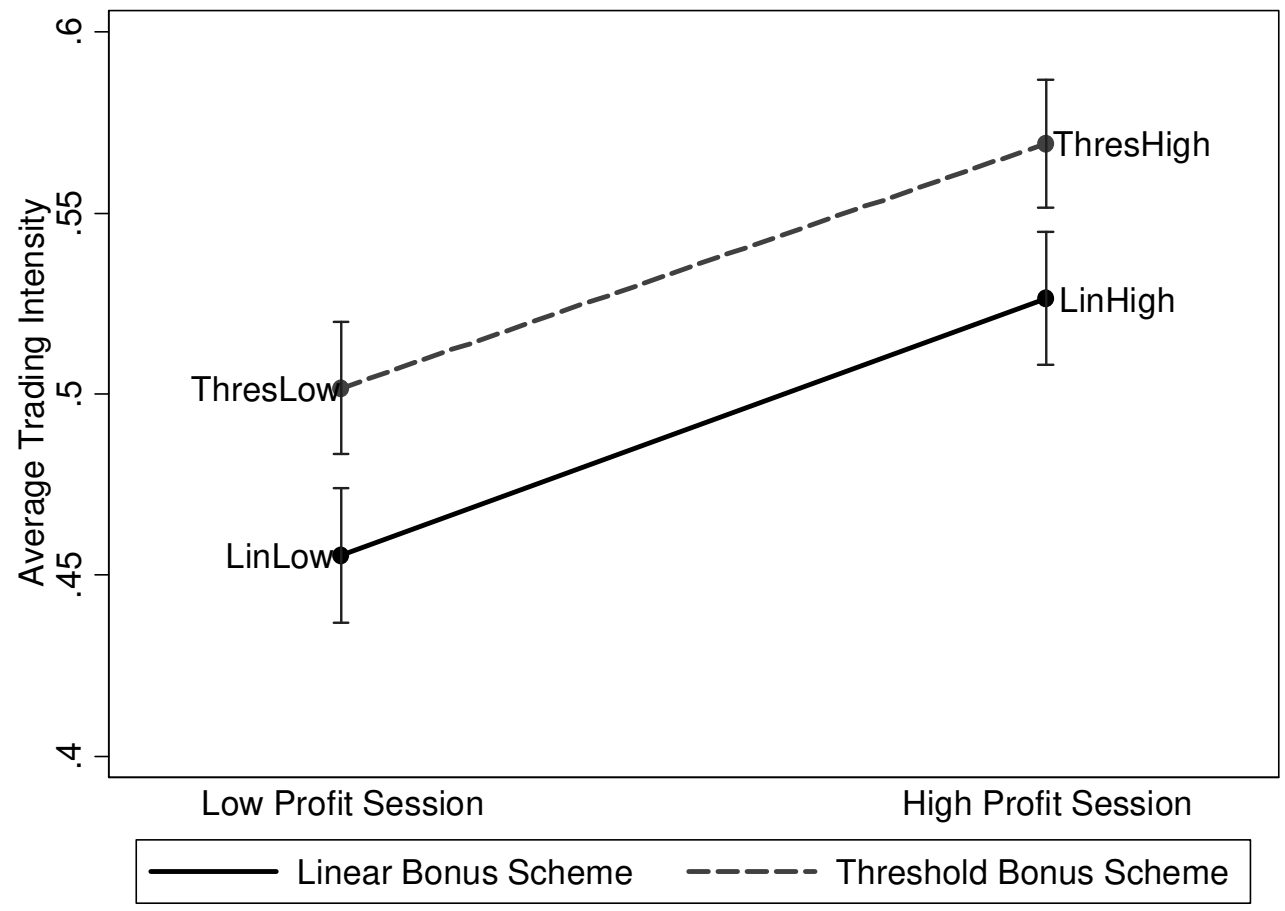


Figure 3 Transaction Frequency by bonus scheme and profitability treatments

Figure 3 shows the average values of Transaction Frequency the four treatments (LinLow, ThresLow, LinHigh, and ThresHigh). Transaction Frequency equals 1 if a trader buys or sells shares in the current round (i.e., if a transaction takes place) and 0 otherwise.

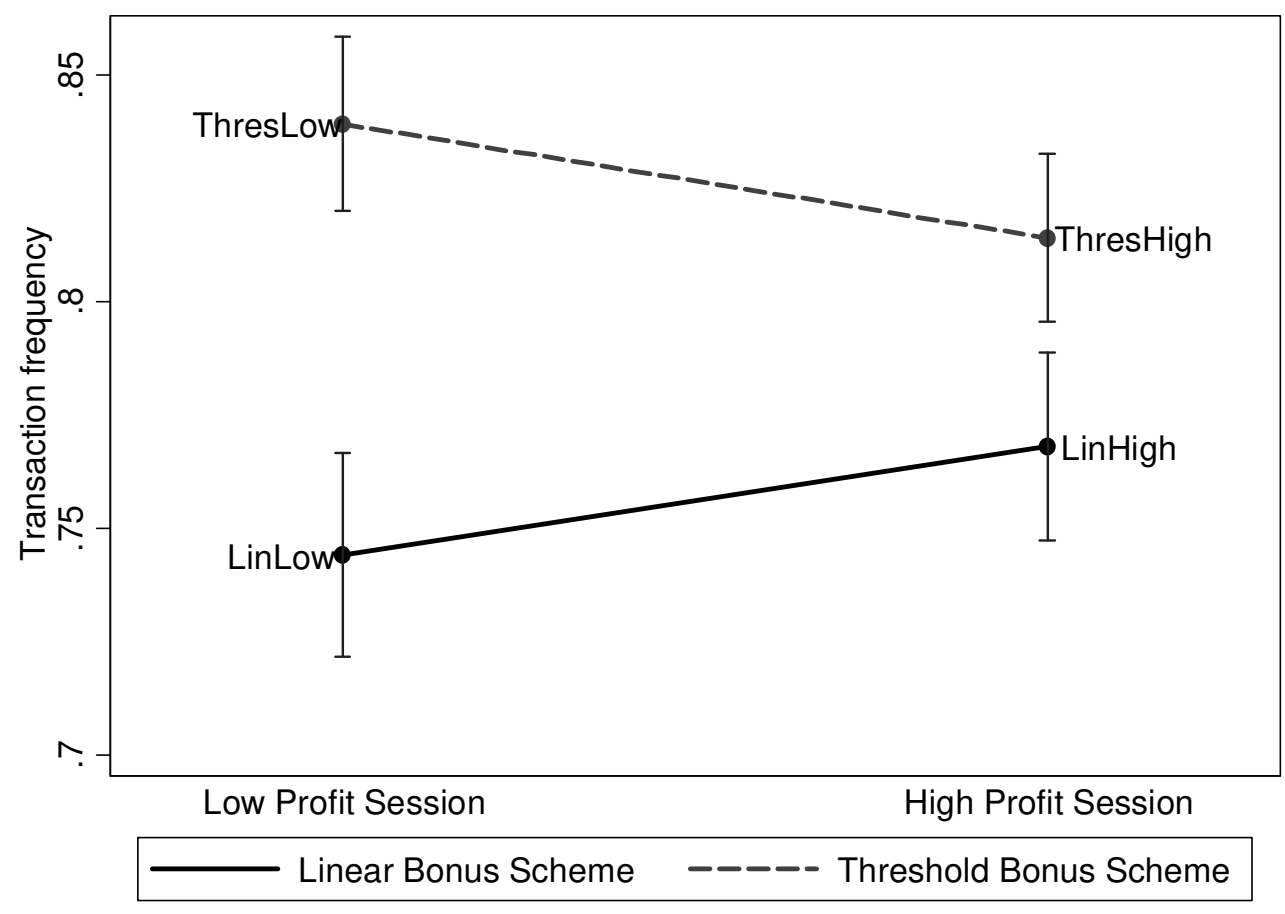


Figure 4 Transaction Size by bonus scheme and profitability treatments

Figure 4 shows the average values of Transaction Size in the four treatments (LinLow, ThresLow, LinHigh, and ThresHigh). The variable Transaction Size equals the number of shares bought (sold) divided by the maximum number of shares the trader could have bought (sold) if a trader buys (sells) shares in the current round.

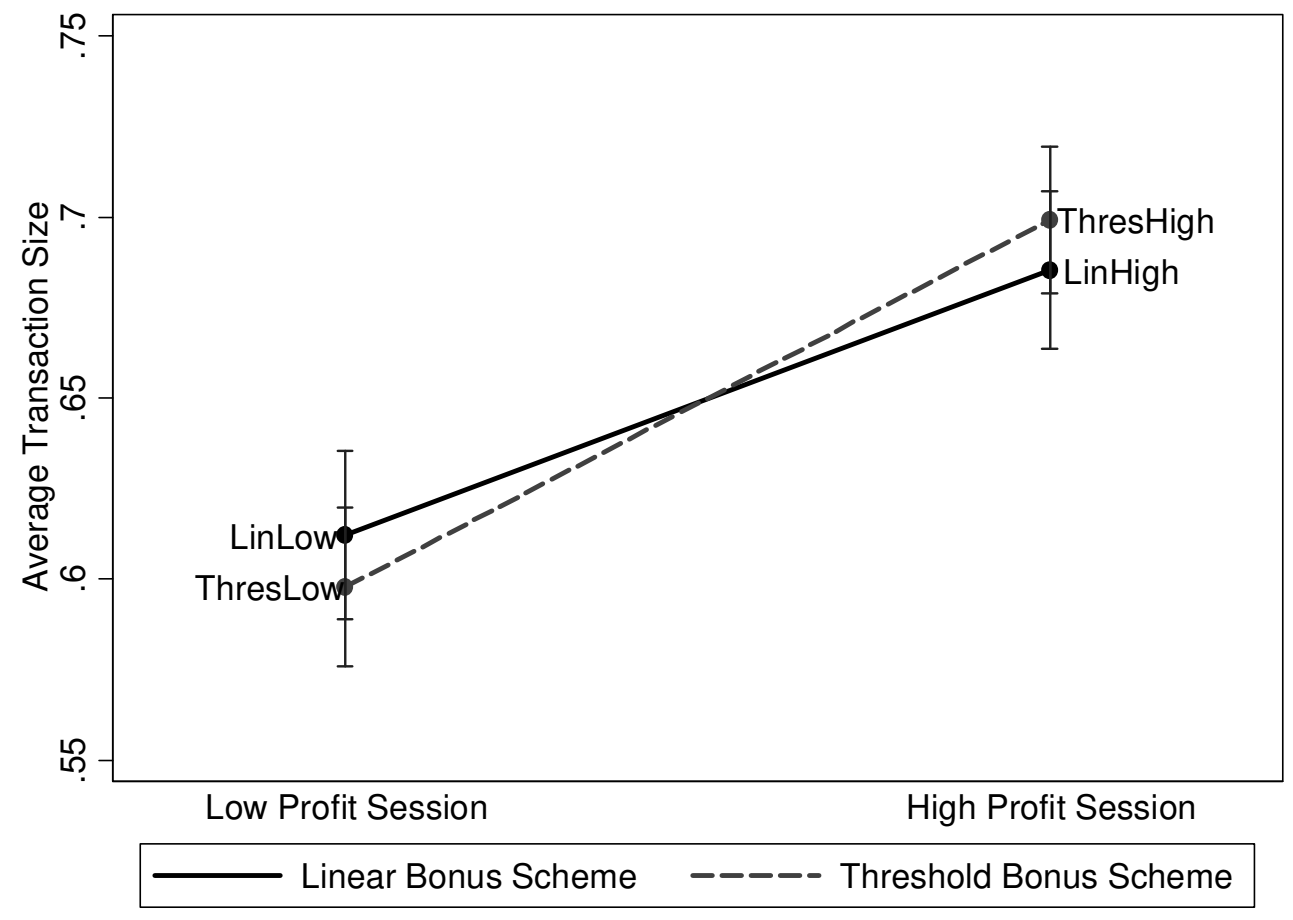


Figure 5 Trader performance and transaction frequency under linear and threshold bonus schemes

Figure 5 shows how transaction frequency changes with the total return earned by a trader under (a) the linear and (b) the threshold bonus schemes. Each bar depicts the transaction frequency (the mean of Transaction Frequency variable) for the given performance percentile.

Figure 5a Linear bonus scheme

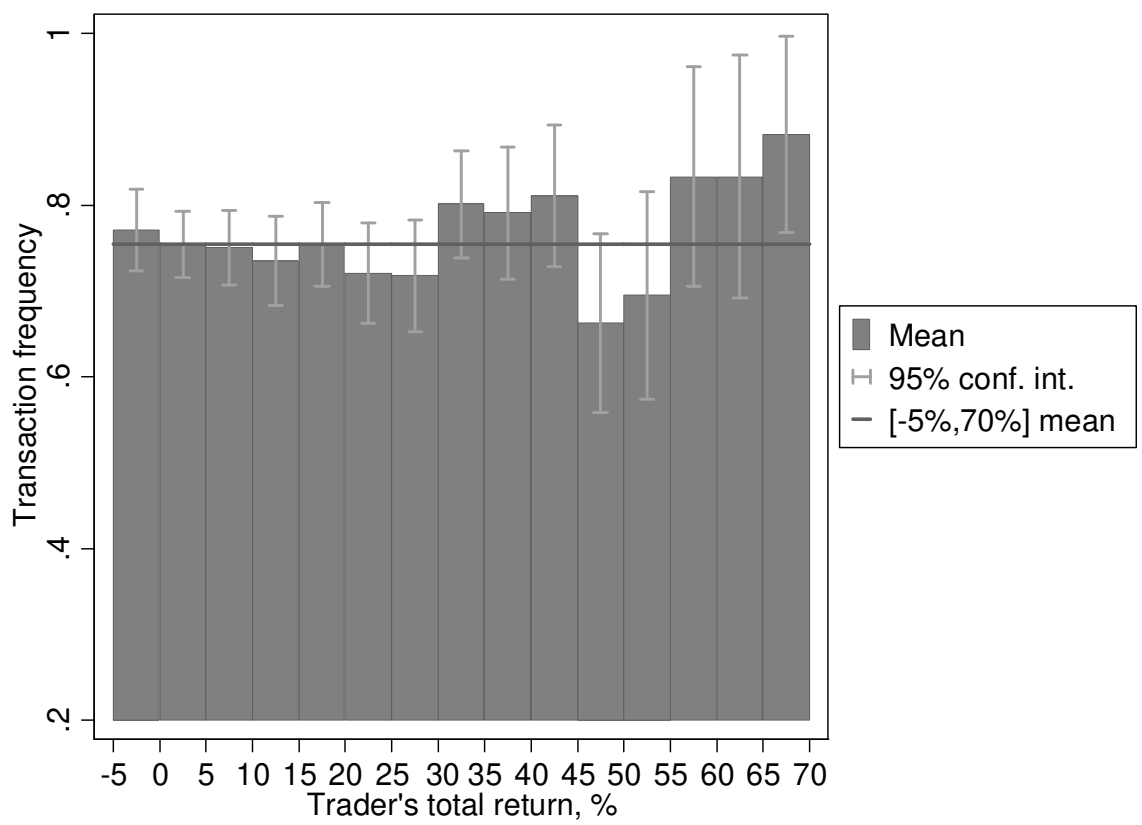

Figure 5b Threshold bonus scheme

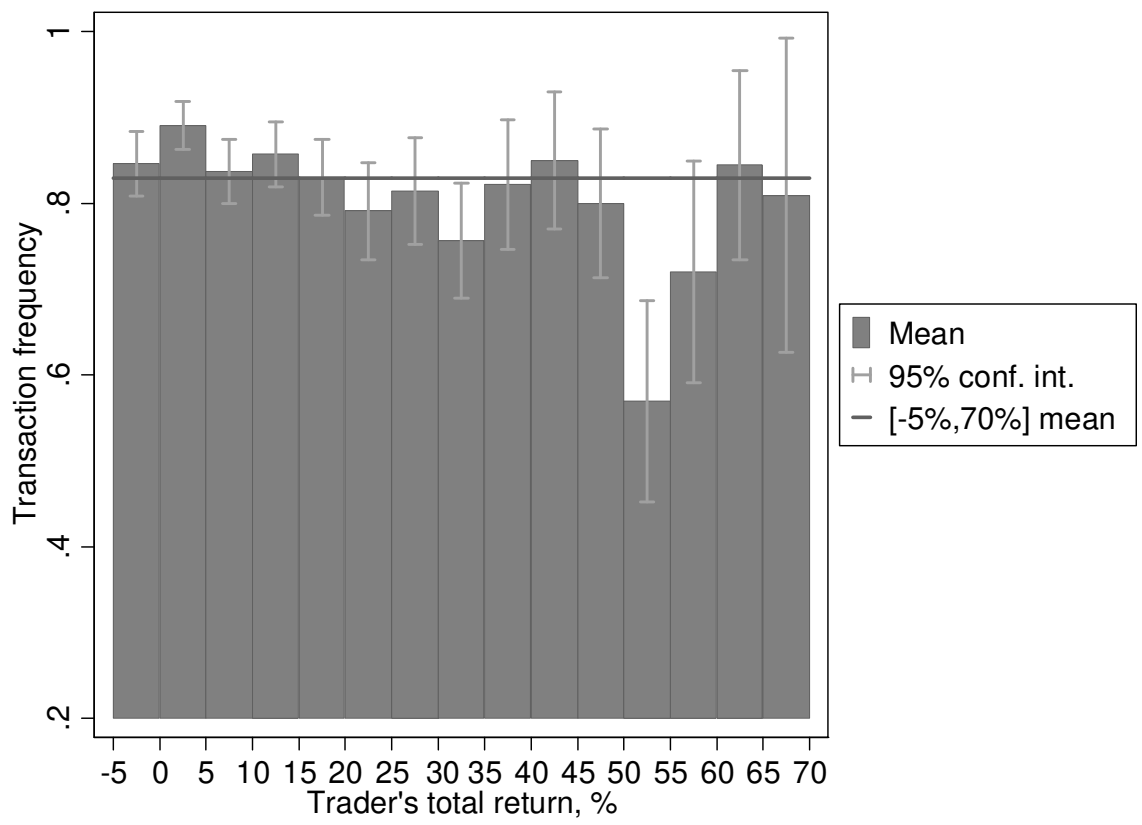




\section{Table 1 Traders' rewards and total return earned}

Table 1 shows how the bonus depends on the final total return obtained under the threshold bonus scheme. A trader receives no bonus if her total return is negative. If the total return is between 0 and $25 \%$, the bonus is $25 \%$ of the profit; a return greater than or equal to $25 \%$ but lower than $45 \%$ yields a bonus of $35 \%$; and a return greater than or equal to $45 \%$ yields a bonus of $45 \%$.

\begin{tabular}{ccccccc}
\hline $\begin{array}{c}\text { Investment } \\
\text { (sum of } \\
\text { endowments) }\end{array}$ & $\begin{array}{c}\text { Value of } \\
\text { total } \\
\text { holdings } \\
\text { (cash and } \\
\text { share) }\end{array}$ & $\begin{array}{c}\text { Profit earned for } \\
\text { trading company } \\
(\mathrm{E} \$)\end{array}$ & $\begin{array}{c}\text { Total } \\
\text { return } \\
(\%)\end{array}$ & $\begin{array}{c}\text { Bonus rate } \\
(\%)\end{array}$ & $\begin{array}{c}\text { Bonus } \\
(\mathrm{E} \$)\end{array}$ & $\begin{array}{c}\text { Bonus } \\
(€)\end{array}$ \\
\hline $5,400.00$ & $5,940.00$ & 540.00 & 10.000 & 25.00 & 135.0 & 2.70 \\
$5,400.00$ & $6,749.99$ & $1,349.99$ & 24.999 & 25.00 & 337.5 & 6.75 \\
$5,400.00$ & $6,750.00$ & $1,350.00$ & 25.000 & 35.00 & 472.5 & 9.45 \\
$5,400.00$ & $7,829.99$ & $2,429.99$ & 44.999 & 35.00 & 850.5 & 17.01 \\
$5,400.00$ & $7,830.00$ & $2,430.00$ & 45.000 & 45.00 & $1,093.5$ & 21.87 \\
$5,400.00$ & $8,640.00$ & $3,240.00$ & 60.000 & 45.00 & $1,458.0$ & 29.16 \\
\hline
\end{tabular}

Table 2 Stock price returns in High and Low Share Return trading sessions

Table 2 compares the stock profitability in the HighSR and LowSR sessions.

\begin{tabular}{lccccccccc}
\hline Group & \#obs. & $\begin{array}{c}\text { Total } \\
\text { return }^{\text {a }}\end{array}$ & $\begin{array}{c}\text { Mean } \\
\text { return }\end{array}$ & $\begin{array}{c}\text { Std. } \\
\text { Dev. }\end{array}$ & Skewness & Kurtosis & p25 & Median & p75 \\
\hline $\begin{array}{l}\text { HighSR } \\
\text { session }\end{array}$ & 50 & 183.385 & 2.354 & 7.183 & -0.049 & 2.776 & -1.795 & 2.027 & 6.527 \\
$\begin{array}{l}\text { LowSR } \\
\text { session }\end{array}$ & 50 & 24.115 & 0.820 & 8.941 & 0.261 & 3.414 & -4.553 & -0.000 & 6.269 \\
\hline
\end{tabular}

a - cumulative stock return at end of trading session, in \%

\section{Table 3 Four treatments}

Table 3 describes the four treatments of the experiment.
LinLow Trading is under the Linear scheme and in the Low Share Return session.
LinHigh Trading is under the Linear scheme and in the High Share Return session.
ThresLow Trading is under the Threshold scheme and in the Low Share Return session.
ThresHigh Trading is under the Threshold scheme and in the High Share Return session. 


\section{Table 4 Trading Intensity by bonus scheme and profitability treatments}

Table 4 compares the trading activity between the four treatments (LinLow, ThresLow, LinHigh, and ThresHigh) in terms of average Trading Intensity. Trading Intensity equals the number of shares bought divided by the maximum number that could be bought plus the number of shares sold divided by the maximum number that could be sold. Trading Intensity equals zero if a trader does not trade in the current round.

Panel A. Mean for Trading Intensity

\begin{tabular}{|c|c|c|c|c|c|}
\hline & \multicolumn{4}{|c|}{ Session profitability } \\
\hline & & Low \& High & Low & High & $\begin{array}{l}\text { Difference between } \\
\text { low- and high- } \\
\text { profitability sessions }\end{array}$ \\
\hline \multirow{4}{*}{ 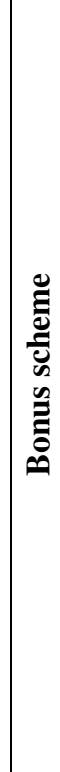 } & Linear \& Threshold & $\begin{array}{c}0.5159 \\
(0.4358) \\
{[6150]}\end{array}$ & $\begin{array}{c}0.4782 \\
(0.4226) \\
{[2850]}\end{array}$ & $\begin{array}{c}0.5485 \\
(0.4444) \\
{[3300]}\end{array}$ & $\begin{array}{l}-0.0703^{* * *} \\
\{6.3251\}\end{array}$ \\
\hline & Linear & $\begin{array}{c}0.4927 \\
(0.4399) \\
{[3050]}\end{array}$ & $\begin{array}{c}\frac{\text { Treatment }}{\underline{\text { LinLow }}} \\
0.4555 \\
(0.4294) \\
{[1450]}\end{array}$ & $\begin{array}{c}\frac{\text { Treatment }}{\underline{\text { LinHigh }}} \\
0.5264 \\
(0.4467) \\
{[1600]}\end{array}$ & $\begin{array}{c}-0.0709^{* * *} \\
\{4.4585\}\end{array}$ \\
\hline & Threshold & $\begin{array}{c}0.5387 \\
(0.4305) \\
{[3100]} \\
\end{array}$ & $\begin{array}{c}\frac{\text { Treatment }}{\text { ThresLow }} \\
0.5017 \\
(0.4142) \\
{[1400]}\end{array}$ & $\begin{array}{c}\frac{\text { Treatment }}{\text { ThresHigh }} \\
0.5692 \\
(0.4413) \\
{[1700]}\end{array}$ & $\begin{array}{l}-0.0675^{* * *} \\
\{4.3581\}\end{array}$ \\
\hline & $\begin{array}{l}\text { Difference between } \\
\text { linear and threshold } \\
\text { schemes }\end{array}$ & $\begin{array}{l}-0.0460^{* * *} \\
\{4.1476\}\end{array}$ & $\begin{array}{l}-0.0462^{* * *} \\
\{2.9220\}\end{array}$ & $\begin{array}{l}-0.0428^{* * *} \\
\{2.7694\}\end{array}$ & \\
\hline
\end{tabular}

The cells contain the means, (standard deviations), and [number of observations]. The right-hand column and the bottom row give the differences between the means of the different groups and the $\{\mathrm{t}$-statistics $\}$. $*$ stands for $\mathrm{p}<0.10, * *$ for $\mathrm{p}<0.05$, and $* * *$ for $\mathrm{p}<0.01$

Note: Higher means indicate a higher average trading intensity during the trading session.

Panel B. ANOVA for Trading Intensity: Variance measure

\begin{tabular}{|l|ccccc|}
\hline Source & $\begin{array}{c}\text { Sum of } \\
\text { Squares }\end{array}$ & Df & $\begin{array}{c}\text { Mean } \\
\text { Square }\end{array}$ & F & P-value \\
\hline ThresBS & 1.521 & 1 & 1.521 & 8.08 & 0.005 \\
HighSR & 3.824 & 1 & 3.824 & 20.31 & 0.000 \\
ThresBS x HighSR & 0.004 & 1 & 0.004 & 0.02 & 0.879 \\
Residual & 1157.149 & 6146 & 0.188 & & \\
Total & 1167.731 & 6149 & 0.190 & & \\
\hline
\end{tabular}


Table 5 Transaction Frequency by bonus scheme and profitability treatments

Table 5 compares the trading activity between the four treatments (LinLow, ThresLow, LinHigh, and ThresHigh) in terms of the average Transaction Frequency. Transaction Frequency equals 1 if a trader buys or sells shares in the current round (i.e. if a transaction takes place) and 0 otherwise.

Panel A. Mean for Transaction Frequency

\begin{tabular}{|c|c|c|c|c|c|}
\hline & \multicolumn{4}{|c|}{ Session profitability } \\
\hline & & Low \& High & Low & High & $\begin{array}{l}\text { Difference between } \\
\text { low- and high- } \\
\text { profitability sessions }\end{array}$ \\
\hline \multirow{4}{*}{ 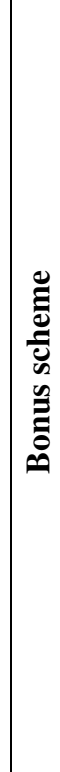 } & Linear \& Threshold & $\begin{array}{c}0.7914 \\
(0.4064) \\
{[6150]}\end{array}$ & $\begin{array}{c}0.7909 \\
(0.4067) \\
{[2850]}\end{array}$ & $\begin{array}{c}0.7918 \\
(0.4061) \\
{[3300]}\end{array}$ & $\begin{array}{c}-0.001 \\
\{0.0905\}\end{array}$ \\
\hline & Linear & $\begin{array}{c}0.7567 \\
(0.4291) \\
{[3050]} \\
\end{array}$ & $\begin{array}{c}\frac{\text { Treatment }}{\underline{\text { LinLow }}} \\
0.7441 \\
(0.4365) \\
{[1450]}\end{array}$ & $\begin{array}{c}\frac{\text { Treatment }}{\underline{\text { LinHigh }}} \\
0.7681 \\
(0.4221) \\
{[1600]}\end{array}$ & $\begin{array}{c}-0.0240 \\
\{1.5420\}\end{array}$ \\
\hline & Threshold & $\begin{array}{c}0.8255 \\
(0.3796) \\
{[3100]} \\
\end{array}$ & $\begin{array}{c}\frac{\text { Treatment }}{\text { ThresLow }} \\
0.8393 \\
(0.3674) \\
{[1400]}\end{array}$ & $\begin{array}{c}\frac{\text { Treatment }}{\text { ThresHigh }} \\
0.8141 \\
(0.3891) \\
{[1700]}\end{array}$ & $\begin{array}{c}0.0252^{*} \\
\{1.8377\}\end{array}$ \\
\hline & $\begin{array}{l}\text { Difference between } \\
\text { linear and threshold } \\
\text { schemes }\end{array}$ & $\begin{array}{l}-0.0688^{* * *} \\
\{6.6583\}\end{array}$ & $\begin{array}{l}-0.0951^{* * *} \\
\{6.2850\}\end{array}$ & $\begin{array}{l}-0.0460^{* * * *} \\
\{3.2565\}\end{array}$ & \\
\hline
\end{tabular}

Cells contain means, (standard deviations), and [number of observations]. The right-hand column and the bottom row give the differences between the means of the different groups and the $\{\mathrm{t}$-statistics .

$*$ stands for $\mathrm{p}<0.10, * *$ for $\mathrm{p}<0.05$, and $* * *$ for $\mathrm{p}<0.01$

Note: Higher means indicate a higher transaction frequency (more transactions made) during the trading session.

Panel B. ANOVA for Transaction Frequency: Variance measure

\begin{tabular}{|l|ccccc|}
\hline Source & $\begin{array}{c}\text { Sum of } \\
\text { Squares }\end{array}$ & Df & $\begin{array}{c}\text { Mean } \\
\text { Square }\end{array}$ & F & P-value \\
\hline ThresBS & 6.448 & 1 & 6.448 & 39.35 & 0.000 \\
HighSR & 0.438 & 1 & 0.438 & 2.67 & 0.102 \\
ThresBS x HighSR & 0.923 & 1 & 0.923 & 5.63 & 0.018 \\
Residual & 1007.150 & 6146 & 0.164 & & \\
Total & 1015.343 & 6149 & 0.165 & & \\
\hline
\end{tabular}




\section{Table 6 Transaction Size by bonus scheme and profitability treatments}

Table 6 compares the trading activity between the four treatments (LinLow, ThresLow, LinHigh, and ThresHigh) in terms of the average Transaction Size. The variable Transaction Size equals the number of shares bought (sold) divided by the maximum number of shares the trader could have bought (sold) if a trader buys (sells) shares in the current round.

\section{Panel A. Mean for Transaction Size}

\begin{tabular}{|c|c|c|c|c|c|}
\hline & \multicolumn{4}{|c|}{ Session profitability } \\
\hline & & Low \& High & Low & High & $\begin{array}{l}\text { Difference between } \\
\text { low- and high- } \\
\text { profitability sessions }\end{array}$ \\
\hline \multirow{4}{*}{ 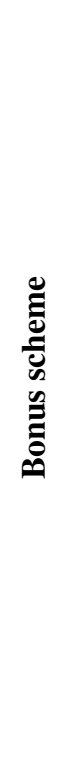 } & Linear \& Threshold & $\begin{array}{c}0.6519 \\
(0.3890) \\
{[4867]}\end{array}$ & $\begin{array}{c}0.6046 \\
(0.3864) \\
{[2254]}\end{array}$ & $\begin{array}{c}0.6927 \\
(0.3866) \\
{[2613]}\end{array}$ & $\begin{array}{l}-0.0880^{* * *} \\
\{7.9213\}\end{array}$ \\
\hline & Linear & $\begin{array}{c}0.6511 \\
(0.3907) \\
{[2308]}\end{array}$ & $\begin{array}{c}\frac{\text { Treatment }}{\text { LinLow }} \\
0.6121 \\
(0.3898) \\
{[1079]}\end{array}$ & $\begin{array}{c}\frac{\text { Treatment }}{\text { LinHigh }} \\
0.6853 \\
(0.3884) \\
{[1229]}\end{array}$ & $\begin{array}{l}-0.0731^{* * *} \\
\{4.5092\}\end{array}$ \\
\hline & Threshold & $\begin{array}{c}0.6526 \\
(0.3875) \\
{[2559]}\end{array}$ & $\begin{array}{c}\frac{\text { Treatment }}{\text { ThresLow }} \\
0.5978 \\
(0.3834) \\
{[1175]}\end{array}$ & $\begin{array}{c}\frac{\text { Treatment }}{\text { ThresHigh }} \\
0.6992 \\
(0.3850) \\
{[1370]}\end{array}$ & $\begin{array}{l}-0.1014^{* * *} \\
\{6.6527\}\end{array}$ \\
\hline & $\begin{array}{l}\text { Difference between } \\
\text { linear and threshold } \\
\text { schemes }\end{array}$ & $\begin{array}{r}-0.0015 \\
\{0.1374\}\end{array}$ & $\begin{array}{r}0.0143 \\
\{0.8800\}\end{array}$ & $\begin{array}{c}-0.0139 \\
\{0.9161\}\end{array}$ & \\
\hline
\end{tabular}

Cells contain means, (standard deviations), and [number of observations]. The right-hand column and the bottom row give the differences between the means of the different groups and the $\{\mathrm{t}$-statistics .

$*$ stands for $\mathrm{p}<0.10, * *$ for $\mathrm{p}<0.05$, and $* * *$ for $\mathrm{p}<0.01$

Note: Higher means indicate a larger transaction size during the trading session.

Panel B. ANOVA for Transaction Size: Variance measure

\begin{tabular}{|l|ccccc|}
\hline Source & $\begin{array}{c}\text { Sum of } \\
\text { Squares }\end{array}$ & Df & $\begin{array}{c}\text { Mean } \\
\text { Square }\end{array}$ & F & P-value \\
\hline ThresBS & 0.116 & 1 & 0.116 & 0.77 & 0.379 \\
HighSR & 3.078 & 1 & 3.078 & 20.60 & 0.000 \\
ThresBS x HighSR & 0.240 & 1 & 0.240 & 1.61 & 0.204 \\
Residual & 726.632 & 4863 & 0.149 & & \\
Total & 736.248 & 4866 & 0.151 & & \\
\hline
\end{tabular}


Table 7 Trading Activity, Transaction Frequency and Transaction Size

\begin{tabular}{|c|c|c|c|c|c|c|}
\hline & $\begin{array}{c}(1) \\
\text { Trading } \\
\text { Intensity } \\
\text { (Tobit) }\end{array}$ & $\begin{array}{c}\text { (2) } \\
\text { Trading } \\
\text { Intensity } \\
\text { (Tobit): } \\
\text { With } \\
\text { Thresholds }\end{array}$ & $\begin{array}{c}\text { (3) } \\
\text { Transaction } \\
\text { Frequency } \\
\text { (Logit) }\end{array}$ & $\begin{array}{c}(4) \\
\text { Transaction } \\
\text { Frequency } \\
\text { (Logit): With } \\
\text { Thresholds }\end{array}$ & $\begin{array}{c}(5) \\
\text { Transaction } \\
\text { Size } \\
\text { (Tobit) }\end{array}$ & $\begin{array}{c}(6) \\
\text { Transaction } \\
\text { Size (Tobit): } \\
\text { With } \\
\text { Thresholds }\end{array}$ \\
\hline ThresBS & $\begin{array}{c}0.074 * * * \\
(0.019)\end{array}$ & $\begin{array}{c}0.077 * * * \\
(0.019)\end{array}$ & $\begin{array}{c}0.575 * * * \\
(0.096)\end{array}$ & $\begin{array}{c}0.597 * * * \\
(0.096)\end{array}$ & $\begin{array}{l}-0.015 \\
(0.015)\end{array}$ & $\begin{array}{l}-0.014 \\
(0.015)\end{array}$ \\
\hline HighSR & $\begin{array}{c}0.020 \\
(0.023)\end{array}$ & $\begin{array}{c}0.010 \\
(0.023)\end{array}$ & $\begin{array}{l}-0.013 \\
(0.106)\end{array}$ & $\begin{array}{l}-0.060 \\
(0.107)\end{array}$ & $\begin{array}{c}0.019 \\
(0.018)\end{array}$ & $\begin{array}{c}0.017 \\
(0.018)\end{array}$ \\
\hline ThresBS x HighSR & $\begin{array}{l}-0.008 \\
(0.027)\end{array}$ & $\begin{array}{c}0.012 \\
(0.027)\end{array}$ & $\begin{array}{c}-0.272 * * \\
(0.130)\end{array}$ & $\begin{array}{l}-0.167 \\
(0.134)\end{array}$ & $\begin{array}{l}0.038 * \\
(0.021)\end{array}$ & $\begin{array}{c}0.044 * * \\
(0.021)\end{array}$ \\
\hline Return $[30 \%, 35 \%]$ & & $\begin{array}{c}0.049 \\
(0.042)\end{array}$ & & $\begin{array}{l}0.347 * \\
(0.206)\end{array}$ & & $\begin{array}{l}-0.007 \\
(0.034)\end{array}$ \\
\hline Return $[50 \%, 55 \%]$ & & $\begin{array}{l}-0.051 \\
(0.079)\end{array}$ & & $\begin{array}{l}-0.271 \\
(0.293)\end{array}$ & & $\begin{array}{c}0.008 \\
(0.062)\end{array}$ \\
\hline $\begin{array}{l}\text { Return }[30 \%, 35 \%] \\
x \text { ThresBS }\end{array}$ & & $\begin{array}{c}-0.128 * * \\
(0.061)\end{array}$ & & $\begin{array}{c}-0.738 * * * \\
(0.284)\end{array}$ & & $\begin{array}{l}-0.023 \\
(0.049)\end{array}$ \\
\hline $\begin{array}{l}\text { Return }[50 \%, 55 \%] \\
x \text { ThresBS }\end{array}$ & & $\begin{array}{c}-0.298 * * * \\
(0.104)\end{array}$ & & $\begin{array}{c}-0.914 * * \\
(0.379)\end{array}$ & & $\begin{array}{c}-0.156^{* *} \\
(0.079)\end{array}$ \\
\hline $\begin{array}{l}\text { Total Return to } \\
\text { Date }\end{array}$ & $\begin{array}{l}-0.001 \\
(0.001)\end{array}$ & $\begin{array}{l}-0.001 \\
(0.001)\end{array}$ & $\begin{array}{l}-0.001 \\
(0.003)\end{array}$ & $\begin{array}{c}0.001 \\
(0.003)\end{array}$ & $\begin{array}{c}-0.001 * * \\
(0.000)\end{array}$ & $\begin{array}{l}-0.001 * \\
(0.000)\end{array}$ \\
\hline $\begin{array}{l}\text { Change in Total } \\
\text { Return }\end{array}$ & $\begin{array}{c}-0.005 * * \\
(0.002)\end{array}$ & $\begin{array}{c}-0.005 * * \\
(0.002)\end{array}$ & $\begin{array}{l}-0.012 \\
(0.009)\end{array}$ & $\begin{array}{l}-0.012 \\
(0.009)\end{array}$ & $\begin{array}{c}-0.004 * * \\
(0.002)\end{array}$ & $\begin{array}{c}-0.004 * * \\
(0.002)\end{array}$ \\
\hline Average \% in Stock & $\begin{array}{l}0.008 * * * \\
(0.000)\end{array}$ & $\begin{array}{l}0.008 * * * \\
(0.000)\end{array}$ & $\begin{array}{l}0.004 * \\
(0.002)\end{array}$ & $\begin{array}{l}0.004 * \\
(0.002)\end{array}$ & $\begin{array}{c}0.009 * * * \\
(0.000)\end{array}$ & $\begin{array}{c}0.009 * * * \\
(0.000)\end{array}$ \\
\hline Stock Return & $\begin{array}{l}0.007 * * * \\
(0.002)\end{array}$ & $\begin{array}{l}0.006 * * * \\
(0.002)\end{array}$ & $\begin{array}{c}0.016 * * \\
(0.008)\end{array}$ & $\begin{array}{c}0.015 * * \\
(0.008)\end{array}$ & $\begin{array}{c}0.005^{* * * *} \\
(0.001)\end{array}$ & $\begin{array}{l}0.005 * * * \\
(0.001)\end{array}$ \\
\hline Market Return & $\begin{array}{c}0.005 * * * \\
(0.002)\end{array}$ & $\begin{array}{l}0.005 * * * \\
(0.002)\end{array}$ & $\begin{array}{c}0.018 * * \\
(0.009)\end{array}$ & $\begin{array}{c}0.020 * * \\
(0.009)\end{array}$ & $\begin{array}{l}0.003 * \\
(0.002)\end{array}$ & $\begin{array}{l}0.003 * \\
(0.002)\end{array}$ \\
\hline Earnings Return & $\begin{array}{c}0.003 \\
(0.002)\end{array}$ & $\begin{array}{c}0.003 \\
(0.002)\end{array}$ & $\begin{array}{c}0.012 \\
(0.010)\end{array}$ & $\begin{array}{c}0.013 \\
(0.010)\end{array}$ & $\begin{array}{c}0.001 \\
(0.002)\end{array}$ & $\begin{array}{c}0.001 \\
(0.002)\end{array}$ \\
\hline $\begin{array}{l}\text { Forecasted Earnings } \\
\text { Return }\end{array}$ & $\begin{array}{c}0.002 \\
(0.002)\end{array}$ & $\begin{array}{c}0.002 \\
(0.002)\end{array}$ & $\begin{array}{c}0.012 \\
(0.008)\end{array}$ & $\begin{array}{c}0.012 \\
(0.008)\end{array}$ & $\begin{array}{l}-0.000 \\
(0.001)\end{array}$ & $\begin{array}{l}-0.000 \\
(0.001)\end{array}$ \\
\hline Round number & $\begin{array}{c}-0.004 * * * \\
(0.001)\end{array}$ & $\begin{array}{c}-0.003 * * * \\
(0.001)\end{array}$ & $\begin{array}{c}-0.016 * * * \\
(0.003)\end{array}$ & $\begin{array}{c}-0.015^{* * * *} \\
(0.003)\end{array}$ & $\begin{array}{c}-0.001 * * * \\
(0.000)\end{array}$ & $\begin{array}{c}-0.001 * * * \\
(0.000)\end{array}$ \\
\hline Constant & $\begin{array}{c}0.095 * * * \\
(0.026)\end{array}$ & $\begin{array}{l}0.089 * * * \\
(0.026)\end{array}$ & $\begin{array}{l}1.290 * * * \\
(0.135)\end{array}$ & $\begin{array}{l}1.257^{*} \\
(0.135\end{array}$ & $\begin{array}{l}0.234 * * * \\
(0.021)\end{array}$ & $\begin{array}{c}0.233 * * * \\
(0.021)\end{array}$ \\
\hline Sigma & $\begin{array}{c}0.503 * * * \\
(0.005)\end{array}$ & $\begin{array}{l}0.502 * * * \\
(0.005)\end{array}$ & & & $\begin{array}{c}0.359 * * * \\
(0.004)\end{array}$ & $\begin{array}{c}0.359 * * * \\
(0.004)\end{array}$ \\
\hline Observations & 6027 & 6027 & 6027 & 6027 & 4766 & 4766 \\
\hline Pseudo R-squared & 0.055 & 0.058 & 0.020 & 0.025 & 0.178 & 0.180 \\
\hline
\end{tabular}

Standard errors are in parentheses. $*, * *$, and $* * *$ stand for $\mathrm{p}<0.10, \mathrm{p}<0.05$, and $\mathrm{p}<0.01$, respectively. 
Table 8 Quality of investment decisions made by traders by bonus scheme and profitability treatments

Table 8 compares the investment decision quality between the four treatments (LinLow, ThresLow, LinHigh, and ThresHigh) in terms of Return Difference. Return Difference is equal to an average share price return for the rounds after purchases minus an average share price return for the rounds after sales.

Panel A. Mean for Return Difference

\begin{tabular}{|c|c|c|c|c|c|}
\hline & \multicolumn{4}{|c|}{ Session profitability } \\
\hline & & Low \& High & Low & High & $\begin{array}{l}\text { Difference between } \\
\text { low- and high- } \\
\text { profitability sessions }\end{array}$ \\
\hline \multirow{4}{*}{ 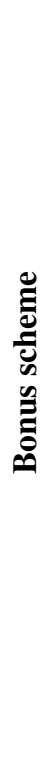 } & Linear \& Threshold & $\begin{array}{c}0.9649 \\
(2.5758) \\
{[122]}\end{array}$ & $\begin{array}{c}1.5760 \\
(2.7486) \\
{[57]}\end{array}$ & $\begin{array}{c}0.4290 \\
(3.3040) \\
{[65]}\end{array}$ & $\begin{array}{c}1.1470^{* *} \\
\{2.5070\}\end{array}$ \\
\hline & Linear & $\begin{array}{c}1.5859 \\
(2.3176) \\
{[60]}\end{array}$ & $\begin{array}{c}\frac{\text { Treatment }}{\text { LinLow }} \\
2.2742 \\
(2.4789) \\
{[29]}\end{array}$ & $\begin{array}{c}\frac{\text { Treatment }}{\text { LinHigh }} \\
0.9421 \\
(1.9854) \\
{[31]}\end{array}$ & $\begin{array}{l}1.3320^{* *} \\
\{2.3046\}\end{array}$ \\
\hline & Threshold & $\begin{array}{c}0.3640 \\
(2.6868) \\
{[62]}\end{array}$ & $\begin{array}{c}\frac{\text { Treatment }}{\text { ThresLow }} \\
0.8530 \\
(2.8690) \\
{[28]}\end{array}$ & $\begin{array}{c}\frac{\text { Treatment }}{\text { ThresHigh }} \\
-0.0388 \\
(2.4978) \\
{[34]}\end{array}$ & $\begin{array}{r}0.8918 \\
\{1.3082\}\end{array}$ \\
\hline & $\begin{array}{l}\text { Difference between } \\
\text { linear and threshold } \\
\text { schemes }\end{array}$ & $\begin{array}{l}1.2220^{* * * *} \\
\{2.6862\}\end{array}$ & $\begin{array}{c}1.4212^{* *} \\
\{2.0033\}\end{array}$ & $\begin{array}{c}0.9809^{*} \\
\{1.7414\}\end{array}$ & \\
\hline
\end{tabular}

Cells contain means, (standard deviations), and [number of observations]. The right-hand column and the bottom row give the differences between the means of the different groups and the $\{\mathrm{t}$-statistics .

$*$ stands for $\mathrm{p}<0.10, * *$ for $\mathrm{p}<0.05$, and $* * *$ for $\mathrm{p}<0.01$

Note: Higher means indicate a higher difference between the share price returns after a purchase and after a sale, i.e., a higher quality of investment decisions.

Panel B. ANOVA for Return Difference: Variance measure

\begin{tabular}{|l|ccccc|}
\hline Source & $\begin{array}{c}\text { Sum of } \\
\text { Squares }\end{array}$ & Df & $\begin{array}{c}\text { Mean } \\
\text { Square }\end{array}$ & F & P-value \\
\hline ThresBS & 28.772 & 1 & 28.772 & 4.73 & 0.0317 \\
HighSR & 26.585 & 1 & 26.585 & 4.37 & 0.0388 \\
ThresBS x HighSR & 1.470 & 1 & 1.470 & 0.24 & 0.6241 \\
Residual & 718.445 & 118 & 6.089 & & \\
Total & 802.774 & 121 & 6.634 & & \\
\hline
\end{tabular}


Table 9 Returns earned by traders at end of trading session by bonus scheme and profitability treatments

Table 9 compares the average returns earned by the traders at the end of the trading session for the four treatments (LinLow, ThresLow, LinHigh, and ThresHigh). The variable Final Total Return is the return earned by a trader at the end of the trading session and equals Total Return at the $50^{\text {th }}$ round.

Panel A. Mean for Final Total Return

\begin{tabular}{|c|c|c|c|c|c|}
\hline & \multicolumn{4}{|c|}{ Session profitability } \\
\hline & & Low \& High & Low & High & $\begin{array}{l}\text { Difference between } \\
\text { low- and high- } \\
\text { profitability sessions }\end{array}$ \\
\hline \multirow{4}{*}{ 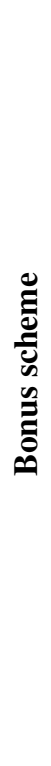 } & Linear \& Threshold & $\begin{array}{c}24.31 \\
(18.67) \\
{[123]}\end{array}$ & $\begin{array}{c}11.86 \\
(12.12) \\
{[57]}\end{array}$ & $\begin{array}{c}35.07 \\
(16.57) \\
{[66]}\end{array}$ & $\begin{array}{l}-23.21^{* * *} \\
\{8.745\}\end{array}$ \\
\hline & Linear & $\begin{array}{c}25.16 \\
(18.06) \\
{[61]}\end{array}$ & $\begin{array}{c}\frac{\text { Treatment }}{\text { LinLow }} \\
14.70 \\
(12.20) \\
{[29]}\end{array}$ & $\begin{array}{c}\frac{\text { Treatment }}{\text { LinHigh }} \\
34.64 \\
(17.38) \\
{[32]}\end{array}$ & $\begin{array}{l}-19.94^{* * *} \\
\{5.136\}\end{array}$ \\
\hline & Threshold & $\begin{array}{c}23.48 \\
(19.37) \\
{[62]}\end{array}$ & $\begin{array}{c}\frac{\text { Treatment }}{\text { ThresLow }} \\
8.92 \\
(11.53) \\
{[28]}\end{array}$ & $\begin{array}{c}\frac{\text { Treatment }}{\text { ThresHigh }} \\
35.47 \\
(16.02) \\
{[34]}\end{array}$ & $\begin{array}{l}-26.55^{* * *} \\
\{7.341\}\end{array}$ \\
\hline & $\begin{array}{l}\text { Difference between } \\
\text { linear and threshold } \\
\text { schemes }\end{array}$ & $\begin{array}{c}1.67 \\
\{0.496\}\end{array}$ & $\begin{array}{c}5.78^{*} \\
\{1.837\}\end{array}$ & $\begin{array}{c}-0.84 \\
\{0.204\}\end{array}$ & \\
\hline
\end{tabular}

Cells contain means, (standard deviations), and [number of observations]. The right-hand column and the bottom row give the differences between the means of the different groups and the $\{\mathrm{t}$-statistics $\}$.

$*$ stands for $\mathrm{p}<0.10, * *$ for $\mathrm{p}<0.05$, and $* * *$ for $\mathrm{p}<0.01$

Note: Higher means indicate higher returns earned by the traders at the end of a trading session.

Panel B. ANOVA for Final Total Return: Variance measure

\begin{tabular}{|l|ccccc|}
\hline Source & $\begin{array}{c}\text { Sum of } \\
\text { Squares }\end{array}$ & Df & $\begin{array}{c}\text { Mean } \\
\text { Square }\end{array}$ & F & P-value \\
\hline ThresBS & 475.654 & 1 & 475.654 & 2.21 & 0.1395 \\
HighSR & 6048.963 & 1 & 6048.963 & 28.14 & 0.0000 \\
ThresBS x HighSR & 334.378 & 1 & 334.378 & 1.56 & 0.2144 \\
Residual & 25583.293 & 119 & 214.986 & & \\
Total & 42546.520 & 122 & 348.742 & & \\
\hline
\end{tabular}




\section{Table 10 Returns earned by traders in second half (at the end of $25^{\text {th }}$ round and later) of trading session}

Table 10 compares the average returns earned by the traders in the second half of the trading session (at the $25^{\text {th }}$ round and later) between the four treatments (LinLow, ThresLow, LinHigh, and ThresHigh) in terms of Total Return to Date. Total Return to Date is equal to return earned by a trader from the beginning of the trading session to the current round, in percentage points.

Panel A. Mean for Total Return to Date

\begin{tabular}{|c|c|c|c|c|c|}
\hline & \multicolumn{4}{|c|}{ Session profitability } \\
\hline & & Low \& High & Low & High & $\begin{array}{l}\text { Difference between } \\
\text { low- and high- } \\
\text { profitability sessions }\end{array}$ \\
\hline \multirow{4}{*}{ 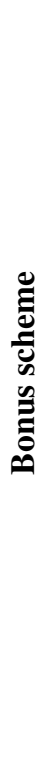 } & Linear \& Threshold & $\begin{array}{l}26.59 \\
(22.52) \\
{[3198]}\end{array}$ & $\begin{array}{c}10.15 \\
(12.67) \\
{[1482]}\end{array}$ & $\begin{array}{c}40.80 \\
(19.26) \\
{[1716]}\end{array}$ & $\begin{array}{c}-30.65^{* * *} \\
\{52.275\}\end{array}$ \\
\hline & Linear & $\begin{array}{c}28.06 \\
(22.72) \\
{[1586]}\end{array}$ & $\begin{array}{c}\frac{\text { Treatment }}{\text { LinLow }} \\
12.35 \\
(12.51) \\
{[754]}\end{array}$ & $\begin{array}{c}\frac{\text { Treatment }}{\text { LinHigh }} \\
42.30 \\
(20.38) \\
{[832]}\end{array}$ & $\begin{array}{l}-29.95^{* * *} \\
\{34.846\}\end{array}$ \\
\hline & Threshold & $\begin{array}{c}25.15 \\
(22.23) \\
{[1612]}\end{array}$ & $\begin{array}{c}\frac{\text { Treatment }}{\text { ThresLow }} \\
7.87 \\
(12.44) \\
{[728]}\end{array}$ & $\begin{array}{c}\frac{\text { Treatment }}{\text { ThresHigh }} \\
39.38 \\
(18.04) \\
{[884]}\end{array}$ & $\begin{array}{l}-31.52^{* * *} \\
\{39.96\}\end{array}$ \\
\hline & $\begin{array}{l}\text { Difference between } \\
\text { linear and threshold } \\
\text { schemes }\end{array}$ & $\begin{array}{l}2.92^{* * * *} \\
\{3.664\}\end{array}$ & $\begin{array}{c}4.48^{* * *} \\
\{6.914\}\end{array}$ & $\begin{array}{l}2.92^{* * *} \\
\{3.147\}\end{array}$ & \\
\hline
\end{tabular}

Cells contain means, (standard deviations), and [number of observations]. The right-hand column and the bottom row give the differences between the means of the different groups and the $\{\mathrm{t}$-statistics .

$*$ stands for $\mathrm{p}<0.10, * *$ for $\mathrm{p}<0.05$, and $* * *$ for $\mathrm{p}<0.01$

Note: Higher means indicate higher returns earned by the traders.

Panel B. ANOVA for Total Return to Date: Variance measure

\begin{tabular}{|l|ccccc|}
\hline Source & $\begin{array}{c}\text { Sum of } \\
\text { Squares }\end{array}$ & Df & $\begin{array}{c}\text { Mean } \\
\text { Square }\end{array}$ & F & P-value \\
\hline ThresBS & 7438.935 & 1 & 7438.935 & 27.54 & 0.0000 \\
HighSR & 354910.074 & 1 & 354910.074 & 1313.92 & 0.0000 \\
ThresBS x HighSR & 484.777 & 1 & 484.777 & 1.79 & 0.1804 \\
Residual & 862749.350 & 3194 & 270.116 & & \\
Total & 1620988.820 & 3197 & 507.034 & & \\
\hline
\end{tabular}




\section{Table 11 Share of wealth invested by traders in stock}

Table 11 compares the average share of wealth invested by the traders in the stock between the four treatments (LinLow, ThresLow, LinHigh, and ThresHigh) in terms of Average \% in Stock. The variable Average $\%$ in Stock is average percentage of a trader's wealth invested in the stock over the trading session.

\section{Panel A. Mean for Average \% in Stock}

\begin{tabular}{|c|c|c|c|c|c|}
\hline & \multicolumn{4}{|c|}{ Session profitability } \\
\hline & & Low \& High & Low & High & $\begin{array}{l}\text { Difference between } \\
\text { low- and high- } \\
\text { profitability sessions }\end{array}$ \\
\hline \multirow{4}{*}{ 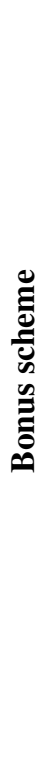 } & Linear \& Threshold & $\begin{array}{c}47.95 \\
(35.24) \\
{[6150]}\end{array}$ & $\begin{array}{c}44.65 \\
(35.14) \\
{[2850]}\end{array}$ & $\begin{array}{c}50.80 \\
(35.08) \\
{[3300]}\end{array}$ & $\begin{array}{l}-6.15^{* * * *} \\
\{6.8486\}\end{array}$ \\
\hline & Linear & $\begin{array}{l}48.02 \\
(36.00) \\
{[3050]}\end{array}$ & $\begin{array}{c}\frac{\text { Treatment }}{\frac{\text { LinLow }}{44.41}} \\
(36.73) \\
{[1450]}\end{array}$ & $\begin{array}{c}\frac{\text { Treatment }}{\frac{\text { LinHigh }}{51.30}} \\
(35.02) \\
{[1600]}\end{array}$ & $\begin{array}{c}-6.88^{* * *} \\
\{5.2969\}\end{array}$ \\
\hline & Threshold & $\begin{array}{l}47.89 \\
(22.23) \\
{[3100]}\end{array}$ & $\begin{array}{c}\frac{\text { Treatment }}{\text { ThresLow }} \\
44.90 \\
(33.41) \\
{[1400]}\end{array}$ & $\begin{array}{c}\frac{\text { Treatment }}{\text { ThresHigh }} \\
50.34 \\
(35.08) \\
{[1700]}\end{array}$ & $\begin{array}{c}5.43^{* * *} \\
\{4.3792\}\end{array}$ \\
\hline & $\begin{array}{l}\text { Difference between } \\
\text { linear and threshold } \\
\text { schemes }\end{array}$ & $\begin{array}{c}0.14 \\
\{0.1541\}\end{array}$ & $\begin{array}{c}-0.49 \\
\{0.3753\}\end{array}$ & $\begin{array}{c}0.96 \\
\{0.7843\}\end{array}$ & \\
\hline
\end{tabular}

Cells contain means, (standard deviations), and [number of observations]. The right-hand column and the bottom row give the differences between the means of the different groups and the $\{\mathrm{t}$-statistics $\}$.

$*$ stands for $\mathrm{p}<0.10, * *$ for $\mathrm{p}<0.05$, and $* * *$ for $\mathrm{p}<0.01$

Note: Higher means indicate percentages of traders' wealth invested in the stock during a trading session.

Panel B. ANOVA for Average \% in Stock: Variance measure

\begin{tabular}{|l|ccccc|}
\hline Source & $\begin{array}{c}\text { Sum of } \\
\text { Squares }\end{array}$ & Df & $\begin{array}{c}\text { Mean } \\
\text { Square }\end{array}$ & F & P-value \\
\hline ThresBS & 173.978 & 1 & 173.978 & 0.14 & 0.7072 \\
HighSR & 36051.654 & 1 & 36051.654 & 29.25 & 0.0000 \\
ThresBS x HighSR & 806.227 & 1 & 806.227 & 0.65 & 0.4187 \\
Residual & 7575727.550 & 6146 & 1232.627 & & \\
Total & 7634460.860 & 6149 & 1241.578 & & \\
\hline
\end{tabular}




\section{Appendix A. Instructions}

Appendix A contains instructions for the trading session under the linear bonus scheme. The instructions under the threshold scheme are identical, except for the calculation of the reward.

This experiment will last about 1.5 hours and will consist of:

1. These instructions and a short quiz;

2. 20 rounds training session;

3. Twice a trading session of 50 rounds;

4. Final questionnaire.

\section{Experimental market}

You will buy and sell shares on behalf of a trading company "Aurum", which will provide you with cash necessary for trading. The amount of cash given to you is called investment. In the 1st round of each trading session you receive $\mathrm{E} \$ 500$ (experimental dollars) from Aurum. In each further round of the session you will get an additional $\mathrm{E} \$ 100$.

Your goal is to maximize Aurum's total return, the ratio of additional money you earn to the investment. You are free to decide how many shares to buy or sell. Choose the optimal trading strategy and buy shares at low prices, sell them at high prices.

Buying and selling shares

Using cash you will be able to buy and sell shares of one company, let's call it "Egias". You can sell/hold previously purchased shares or buy additional ones. Shares and cash together constitute your holdings in every round. You will start with 0 shares. So in the first round you cannot sell shares; you can only buy shares. The maximum number of shares you can buy multiplied by the current share price cannot exceed your current cash holdings. See Example 1.

\section{Example 1}

You have $\mathrm{E} \$ 119$ in cash and the current share price is $\mathrm{E} \$ 30$.

The maximum number of shares you can buy equals 3 , as $3 \times \mathrm{E} \$ 30=\mathrm{E} \$ 90<\mathrm{E} \$ 119$.

You cannot buy 4 shares as $4 \times \mathrm{E} \$ 30=\mathrm{E} \$ 120>\$ \mathrm{E} 119$.

If you buy 3 shares, then $\mathrm{E} \$ 29$ is left in your cash holdings.

When you buy shares:

- your cash holdings are reduced by the number of shares bought multiplied by the current share price;

- your share holdings (or shares' value) are increased by the same amount;

- the number of shares you own increases by the number of shares bought. 


\section{When you sell shares:}

- your cash holdings are increased and your share holdings are decreased by the number of shares sold multiplied by the current share price;

- the number of shares you own decreases by the number of shares sold.

If you do not buy nor sell any shares, then the number of shares you own stays the same, but the value of your shares may increase or decrease depending on the share price movement. See example 2.

\section{Example 2}

In the beginning of the current round you own 20 shares and $\mathrm{E} \$ 1,000$ cash. The current share price is $\mathrm{E} \$ 10$.

The share holdings are $20 \mathrm{xE} \$ 10=\mathrm{E} \$ 200$ and the total holdings are $\mathrm{E} \$ 1,200$.

You buy 10 more shares at the current price and spend $\mathrm{E} \$ 100$ cash such that you have $\mathrm{E} \$ 900$ left $(\mathrm{E} \$ 900=\mathrm{E} \$ 1,000-\mathrm{E} \$ 100)$.

In the next round the share price rises up to $\mathrm{E} \$ 15$ and your share holdings equal 30 shares $\mathrm{x} \$ 15$ $=\mathrm{E} \$ 450$.

In the beginning of the next round you will have $\mathrm{E} \$ 1000$ in cash because you also receive $\mathrm{E} \$ 100$ extra cash from Aurum in the beginning of each round.

Your total holdings are $\mathrm{E} \$ 1450=\mathrm{E} \$ 1000$ (cash) + $\mathrm{E} \$ 450$ (shares).

\begin{tabular}{|c|c|c|c|c|c|}
\hline & $\begin{array}{l}\text { Cash } \\
\text { holdings }\end{array}$ & $\begin{array}{l}\text { Share } \\
\text { holdings }\end{array}$ & $\begin{array}{l}\text { Number of } \\
\text { shares owned }\end{array}$ & $\begin{array}{l}\text { Total } \\
\text { holdings }\end{array}$ & $\begin{array}{l}\text { Share } \\
\text { price }\end{array}$ \\
\hline Beginning of the current round & $\mathrm{E} \$ 1,000$ & E\$200 & 20 shares & $\mathrm{E} \$ 1,200$ & $\mathrm{E} \$ 10$ \\
\hline \multicolumn{6}{|l|}{ Your decision: +10 shares } \\
\hline End of the current round & $\mathrm{E} \$ 900$ & $\mathrm{E} \$ 300$ & 30 shares & $\mathrm{E} \$ 1,200$ & $\mathrm{E} \$ 10$ \\
\hline \multicolumn{6}{|c|}{ In the beginning of the next round, the share price goes up by $\mathrm{E} \$ 5$} \\
\hline Beginning of the next round & $\mathrm{E} \$ 1,000$ & $\mathrm{E} \$ 450$ & 30 shares & $\mathrm{E} \$ 1,450$ & $\mathrm{E} \$ 15$ \\
\hline
\end{tabular}




\section{Trading stage}

Every trading round starts with a trading stage, where you can buy and/or sell shares.

Screenshot of a trading stage

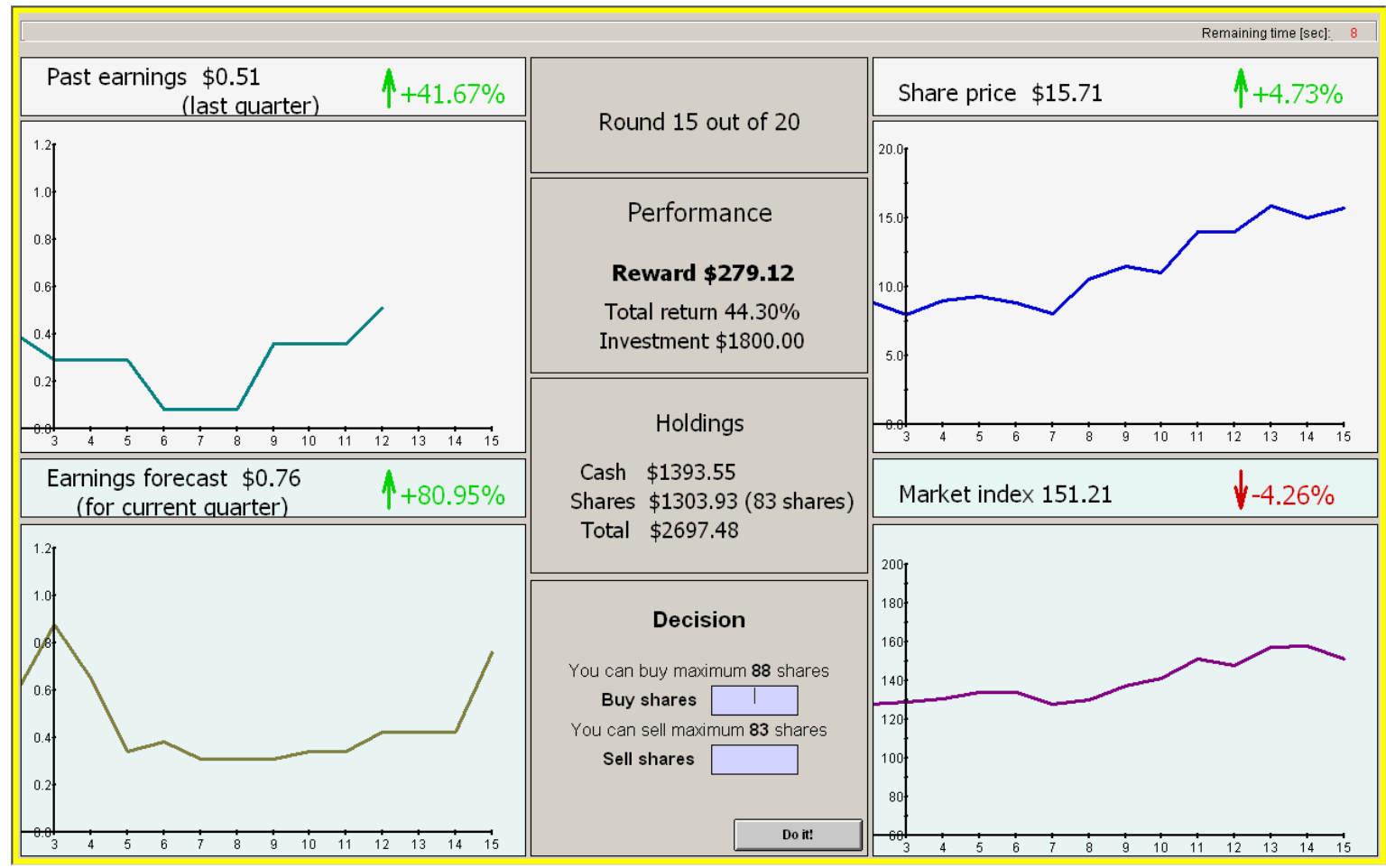

This screen shows the information helpful in your investment decisions:

- Egias' share price,

- the market index,

- Egias' earnings information (past and forecast),

- your current holdings and performance;

- in the same screen you can make your investment decisions.

The upper right corner of the screen shows the time remaining for your decision in the current round. The screen will appear for 15 seconds. Within 15 seconds you must specify your decision whether you want to buy or sell shares. If you do not reach any decision within $15 \mathrm{sec}$, you will proceed to the next round with your share holdings unchanged.

To the left you see past Egias' earnings and earnings forecast. You also see percentage changes in earnings and earnings forecasts from the last past round and the graphs of historical values of earnings and earnings forecasts (up to 12 past rounds), which give you a broader picture and could allow you to identify a link between earnings and their forecasts.

Company's earnings are an after-tax profit (or loss), which a company produces during a specific time period. For example, Egias calculates and reports its earnings every three rounds. In 
some periods companies generate profit (and their earnings are positive), whereas in other periods companies can incur losses (earnings are negative). On the screen you see Egias' earnings per share (earnings divided by the number of shares outstanding, which is constant throughout all sessions).

An earnings forecast is value of earnings expected by analysts for the next period. Analyst is a person who studies company's accounts, strategy, and economic outlook. On the screen you see the average expected value from many analysts.

In the right bottom corner you see the current market index value, its percentage change from the last past round, and a graph of its historical values (up to 12 past rounds).

- The market index measures the price changes of the overall stock market, which consists of all publicly traded companies. Changes in the market index reflect changes in the whole economy. For example, a recession is typically accompanied by a drop in the market index and the economic expansion goes along with an increase in the market index.

The share price may be influenced by past earnings, earnings forecast, and by the market index movements, but the degree of this relation may in some time periods be strong or weak and may occasionally be inversed.

In the right upper corner you see the current share price, its percentage change and the graph of its historical values (up to 12 past rounds).

\section{The central part of the screen contains the following four boxes (down):}

1. Round shows the current round and the total number of rounds in the current trading session.

2. Performance shows your current reward, the total return you earned for Aurum and the total investment you received from Aurum.

3. Holdings shows your current cash and share holdings, including the number of shares owned. Total holdings equal the sum of cash and share value.

4. Decision, where you can specify the number of shares you want to buy or sell.

a. If you want to buy shares, specify the number you want to buy in the upper blue box. Leave it blank if you don't want to buy any shares.

b. If you want to sell shares, specify the number you want to sell in the lower blue box. Leave it blank if you don't want to sell any shares.

c. If you don't want to buy nor sell any shares, leave both blue boxes blank.

d. Press the button "Do it!" when you are ready with your investment decisions and you will automatically proceed to the next round. If you don't press the button before the time is over, then your decisions will not be executed.

The experimental stock market employs real historical share price, earnings, earnings forecast, and market index data. So it is fully independent from your decisions/performance or the decisions/performance of other participants. 


\section{Reward calculation}

For your services you will receive a reward. It depends on your own performance: the more you earn for Aurum, the more you get as a reward. Your reward is calculated at the end of each trading session and constitutes a fixed percent, 35\% of the additional money (additional money = holdings - investment) you earned for Aurum over the entire 50 rounds.

If total return $>0$, then reward $=($ holdings - investment $) \times 35 \%$

If total return is negative, then your reward is zero.

Total return $=($ holdings - investment $) /$ investment

\section{Example 3}

After 50 rounds your holdings (combined in cash and shares) equal $\mathrm{E} \$ 7,400$, whereas the total investment from Aurum was E\$5,400.

So you have earned $\mathrm{E} \$ 7,400$ - $\mathrm{E} \$ 5,400=\mathrm{E} \$ 2,000$ of additional money for Aurum and the total return is $\mathrm{E} \$ 2,000 / \mathrm{E} \$ 5,400=32.07 \%>0$.

Your reward is $\mathrm{E} \$ 2,000 \times 35 \%=\mathrm{E} \$ 700=€ 14$.

Below is a graph of the final reward depending on total return you earn for Aurum at the end of the trading session.

\section{Reward}

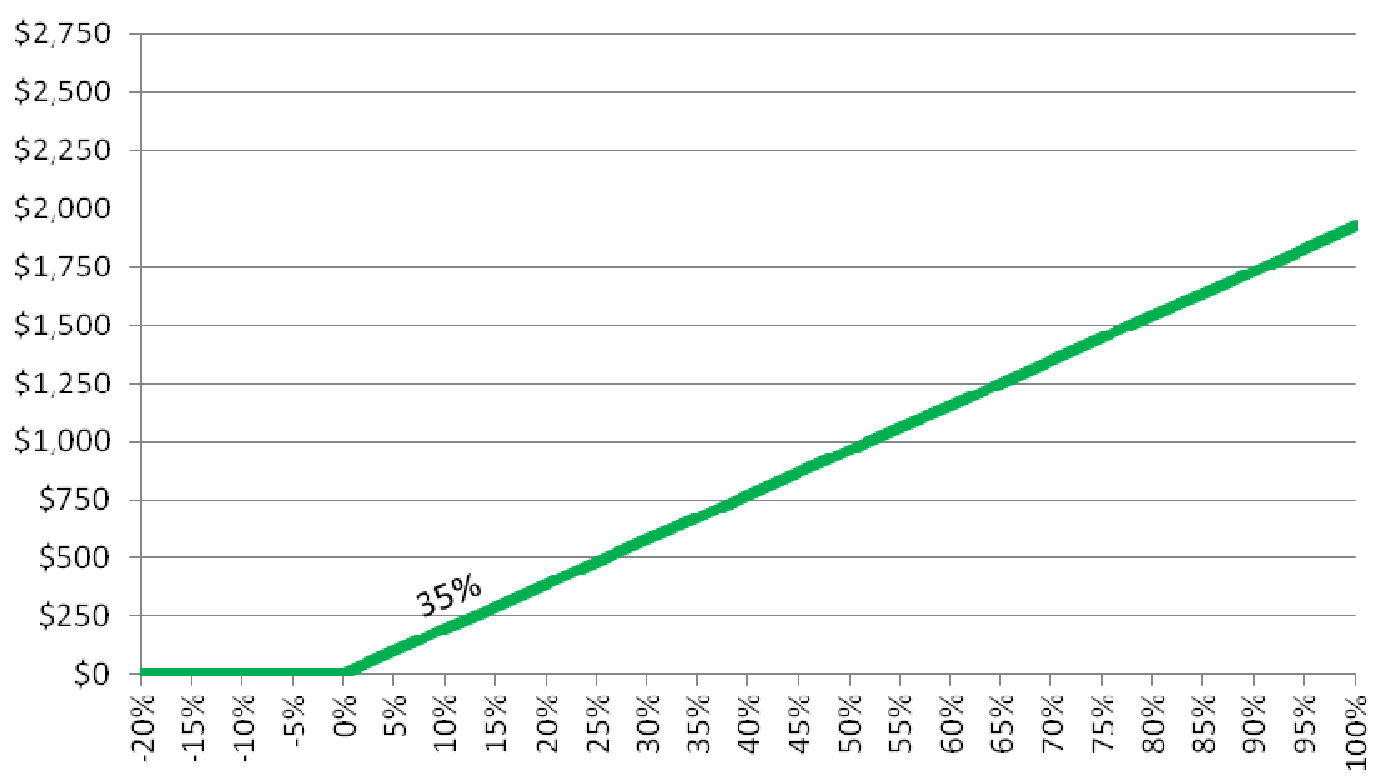

Total return 


\section{Performance stage}

After the decision stage you will be shown a screen with your performance to date (resulting from the previous rounds) for $2 \mathrm{sec}$. Your current reward, the total return earned for Aurum, and investment will appear in the upper box of the screen. In the lower box you will see a graphical representation of your reward depending on the total return earned for Aurum. On the graph the $\mathrm{x}$-axis is the total return earned for Aurum, and the y-axis is your reward. Two arrows show your current performance in terms of reward and the total return earned for Aurum.

\section{Screenshot of a performance stage}

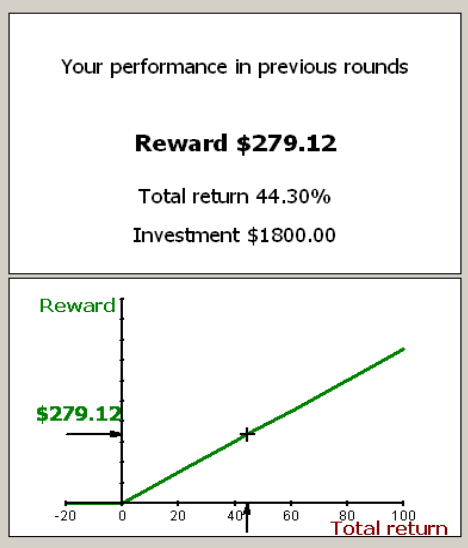

\section{Final payoff}

You earn $€ 2$ for showing up. The variable part of your payment depends on your performance during the experiment. Your final payoff will be randomly chosen from two rewards earned in the two trading sessions.

For example,

- $\mathrm{E} \$ 650(€ 13)$ is your reward in the 1 st trading session

- $\mathrm{E} \$ 800(€ 16)$ is your reward in the 2nd trading session

One trading session will be randomly selected to determine your payment. You will be paid your total reward in cash and in private at the end of the experiment.

Now you will start with a training session, which aims to familiarize you with the experimental environment and does not count towards your final payment. 
Appendix B. Variable definitions

\begin{tabular}{|c|c|}
\hline Variable name & Description \\
\hline Average \% in Stock & $\begin{array}{l}\text { Average percentage of a trader's wealth invested in the stock over the } \\
\text { trading session. }\end{array}$ \\
\hline Change in Total Return & $\begin{array}{l}\text { Difference between total return earned by a trader from the beginning of } \\
\text { the trading session to the current round (Total Return to Date) and total } \\
\text { return earned from the beginning of the trading session to the previous } \\
\text { round, in percentage points. }\end{array}$ \\
\hline Earnings Return & $\begin{array}{l}\text { Return in earnings relative to previous round (current versus previous } \\
\text { round), in percentage points. }\end{array}$ \\
\hline Final Total Return & $\begin{array}{l}\text { Return earned by a trader at the end of the trading session, which equals } \\
\text { Total Return at the } 50^{\text {th }} \text { round }\end{array}$ \\
\hline Forecasted Earnings Return & $\begin{array}{l}\text { Most recent forecasted earnings return (current versus previous round), } \\
\text { in percentage points. }\end{array}$ \\
\hline HighSR & $\begin{array}{l}\text { Dummy for the high-stock-return session, which equals } 1 \text { if the current } \\
\text { trading session has high-profitability conditions and } 0 \text { otherwise. }\end{array}$ \\
\hline Market Return & $\begin{array}{l}\text { Most recent return of the market index (current versus previous round), } \\
\text { in percentage points. }\end{array}$ \\
\hline Return $[30 \%, 35 \%]$ & $\begin{array}{l}\text { Dummy variable, which equals } 1 \text { when a trader's Total Return to Date is } \\
\text { between } 30 \% \text { and } 40 \% \text {. }\end{array}$ \\
\hline Return $[50 \%, 55 \%]$ & $\begin{array}{l}\text { Dummy variable, which equals } 1 \text { when a trader's Total Return to Date is } \\
\text { between } 50 \% \text { and } 60 \% \text {. }\end{array}$ \\
\hline Return $[30 \%, 35 \%] \times$ ThresBS & Interaction term between Return $[30 \%, 40 \%]$ and ThresBS. \\
\hline Return $[50 \%, 55 \%] \times$ ThresBS & Interaction term between Return $[50 \%, 60 \%]$ and ThresBS. \\
\hline Return Difference & $\begin{array}{l}\text { Average share price return for the rounds after purchases minus average } \\
\text { share price return for the rounds after sales. }\end{array}$ \\
\hline Round Number & Number of the current trading round. \\
\hline ThresBS & $\begin{array}{l}\text { Dummy for the threshold bonus scheme, which equals } 1 \text { if in the current } \\
\text { trading session a trader operates under the threshold scheme and zero for } \\
\text { the linear bonus scheme. }\end{array}$ \\
\hline ThresBS x HighSR & Interaction term between ThresBS and HighSR. \\
\hline Total Return to Date & $\begin{array}{l}\text { Total return earned by a trader from the beginning of the trading session } \\
\text { to the current round, in percentage points. }\end{array}$ \\
\hline Trading Intensity & $\begin{array}{l}\text { The number of shares bought divided by the maximum number that } \\
\text { could be bought plus the number of shares sold divided by the maximum } \\
\text { number that could be sold. }\end{array}$ \\
\hline Transaction Frequency & $\begin{array}{l}\text { Dummy variable, which equals } 1 \text { if a trader buys or sells shares in the } \\
\text { current round (i.e., if a transaction takes place) and } 0 \text { otherwise. }\end{array}$ \\
\hline Transaction Size & $\begin{array}{l}\text { Number of shares bought (sold) divided by the maximum number of } \\
\text { shares the trader could have bought (sold) if a trader buys (sells) shares } \\
\text { in the current round. }\end{array}$ \\
\hline Stock Return & $\begin{array}{l}\text { Most recent stock return (current versus previous round), in percentage } \\
\text { points. }\end{array}$ \\
\hline
\end{tabular}
points. 